\title{
Trade Policy Barriers: An Obstacle to Export Diversification in Eurasia
}

\author{
Ana Paula Cusolito ${ }^{1}$ \\ World Bank Group, USA \\ acusolito@worldbank.org \\ Claire H. Hollweg \\ World Bank Group, USA \\ chollweg@worldbank.org
}

\begin{abstract}
Despite trade liberalization efforts made by Eurasian countries, the export structure of the region shows significant levels of concentration across export destinations. To shed light on this observation, this research analyzes trade policy barriers in Eurasia, East Asia and the Pacific, and the European Union. Using the most recent data from sources including the World Trade Organization, the United Nations, and the World Bank - including the Overall Trade Restrictiveness Indices, the Services Trade Restrictions Database, and the Temporary Trade Barriers Database - the role of tariffs, non-tariff measures, temporary trade barriers, trade agreements, and trade barriers in services are explored to explain the lack of diversification by destination. Several conclusions can be drawn from the analysis. First, China, Korea, and Japan, as well as the European Union, impose high levels of protection on products of animal origin, which may explain the lack of Eurasian export diversification toward the East Asia and the Pacific and the European Union regions. It also highlights the potential benefits of diversifying the structure of production in Eurasia toward more sophisticated and technologically intensive goods. Second, the East Asia and the Pacific region (especially China) appears to be more protectionist than the European Union, suggesting a greater challenge for Eurasian countries in diversifying exports to the destination. And third, few or no regional trade agreements exist between Eurasian countries and countries in the European Union or East Asia and the Pacific.
\end{abstract}

\section{JEL classification: F13; F15}

Keywords: Export diversification, trade policy barriers, tariffs, non-tariff measures, preferential trade agreements

The corresponding author can be contacted at acusolito@worldbank.org, +1 (202) 473-7699 (telephone), +1 (202) 522-7551 (fax), 1818 H St. NW, Washington, DC 20433 USA. The findings, interpretations, and conclusions expressed in this paper are entirely those of the authors. They do not represent the view of the World Bank, its Executive Directors, or the countries they represent. 


\section{INTRODUCTION}

During the past decade, countries have made important progress to liberalize their economies by removing quantitative import restrictions and reducing tariffs. Trade liberalization has been shown to have important effects on export diversification that operate through a variety of channels, such as enhancing firms' productivity and ability to export. This includes trade liberalization in the exporting country itself, but also in importing partner countries. But in practice, tariffs and other trade policy barriers are still high enough to create anti-export bias and significant obstacles to trade diversification.

On the one hand, trade policy barriers in an exporting country can affect the country's own export performance. Import duties on final goods increase product prices, make the production of import substitutes profitable, and induce factors of production reallocations from exporting to domestic sectors, which increase the costs of producing new tradable goods. Lower output tariffs expose formerly protected plants to foreign competition, forcing high-cost, low-productivity domestic firms to improve their operations or exit the market (Pavcnik, 2002; Trefler, 2004). Furthermore, tariffs on intermediate inputs used by exporters decrease the range of foreign inputs available to produce new varieties, raise production costs, and squeeze margins. Tariff reductions provide benefits to exporters through increased access to previously unavailable or cheaper inputs (Goldberg et al., 2010; Rodriguez-Clare and Klenow, 1997), which is shown to have a positive influence on productivity via learning, variety, or quality effects (Amiti and Konings, 2005; Ferreira and Rossi, 2003). As exemplified in India, Indonesia and Brazil, access to cheaper and superior foreign inputs allow domestic firms to save costs, augment their productivity, and become more productive and competitive (Amiti and Konings, 2005; Schor 2004; Topalava and Khandelwal, 2011). Mukerji (2009) shows that trade liberalization in India through a lowering of tariffs boosted the number of imported varieties by as much as 18 percent in the post-liberalization era. Input tariff liberalization also promotes growth from technological innovation embedded in foreign inputs and learning by doing, as Tybour and Westbrook (1993) show for Mexico.

Regulatory reforms in the domestic services market has been shown to also impact a country's export diversification. Such reforms increase competition, efficiency, and lower the price of services inputs, which enhance firms' productivity and probability of exporting (Arnold et al., 2012; Bas, 2013). Berulava (2011) shows that liberalizing reforms in telecommunications, electric power, railway transport, road transport, water distribution and banking sectors strengthen existing manufacturing exports to current destinations, lure in new exporters, and encourage exports to explore new destinations of manufacturing.

On the other hand, trade policy barriers in an importing country increase the costs of accessing that market and also damage exporters' extensive margins, that is, new products and new markets. There exists an extensive amount of literature that sheds light on the impact of opening up the importing country to foreign trade on export diversification. Tariff reductions in a trading partner result in large and significant changes in the extensive margin of the exporting country, increasing the number of products produced and exported (Debaere and Mostashari, 2010; Kehoe and Ruhl, 2002). One channel is via learning-by-exporting, whereby exporting firms are more likely to adopt advanced technologies that increase efficiency (Baldwin and $\mathrm{Gu}, 2004$ ). Non-tariff measures in an importing country can make it costly for firms to export. Basedina (2015), however, finds no evidence that technical barriers to trade and sanitary and phytosanitary measures - two types of non-tariff measures - have an impact on a country's extensive margin of trade.

Tariff reductions by way of bilateral or plurilateral trade agreements has also been shown to impact export diversification between countries party to the agreement, but also to countries outside the agreement. For example, the free trade agreement between New Zealand and Australia - the Closer Economic Relationship - led to a widening rather than a deepening of New Zealand's exports, with exports of new products contributing more to export growth than 
expanding exports of existing products (Sandrey and Seventer, 2004). The number of products exported (new varieties) by the United States to NAFTA members relative to other counties in the world increased after its inception in 1993 (Hillberry and McDaniel, 2002). "In the presence of sunk costs, preferential tariff liberalization has prolonged, dynamic effects on the pattern of a beneficiary country's exports, as they trigger a geographic spread of exports to third markets outside the preferential trade area," exemplified by NAFTA paving the way for Mexico to grow exports to additional destinations in Latin America (Borchert, 2007).

Despite the trade liberalization efforts made by the region, the export structure of Eurasian countries shows significant levels of concentration across export destinations (Figure 1). ${ }^{2} \mathrm{~A}$ large percentage of the region's exports go to the European Union (EU). Between 2000 and 2010, Eurasia sent on average $47.5 \%$ of its annual exports to the EU. Exports to the East Asia and the Pacific (EAP) region were mainly oriented to China, a destination that accounted for, on average, $6.6 \%$ of the region's total annual exports during the same period. China's importance as an export destination has increased since the global financial crisis of $2008+$. In $2008,5.5 \%$ of Eurasia's exports went to this country, increasing to $8.1 \%$ in 2010 . The significance of the EU has decreased since 2006, from $50.6 \%$ to $47.4 \%$ in 2010. In terms of value, exports to both the EU and EAP countries declined in 2009 following the advent of the crisis, although exports to China experienced the least relative decline. Only exports to the EU had not returned to pre-crisis levels by 2010 .

\section{Figure 1}

Eurasia’s Exports by Destination

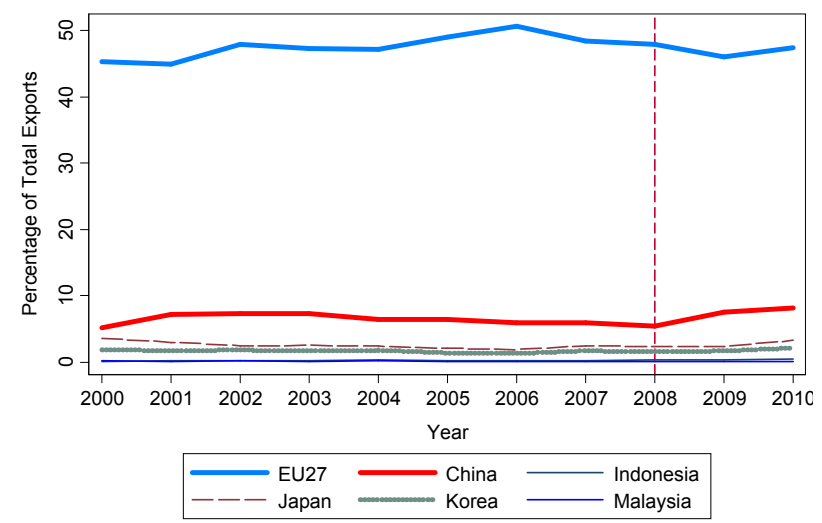

Figure 1 presents destination shares of Eurasia's exports between 2000 and 2010.

Source: Authors' calculations using data from United Nations'(UN) Comtrade accessed through World Integrated Trade Solutions (WITS) (2012).

The export structure of the region is also concentrated at the product level (Figure 2). Mineral products and base metals explain, on average, $83.9 \%$ of the annual exports sent to the EU, and $62.4 \%$ of the annual exports sent to EAP. In both cases, there is a clear increment of the importance of mineral products in the export basket. However, the change is more notable in the case of EAP. The increment involved a variation of 48.3 percentage points, from $11.8 \%$ in 2000 to $60.1 \%$ in 2010 . In the case of the EU, mineral products accounted for $63.8 \%$ of the total exports in 2000 and $79.7 \%$ in 2010 . The fact that both regions are importing similar products from Eurasia suggests that the lack of export diversification towards EAP may not be driven exclusively by trade complementarity reasons. It may well be explained by trade policy issues that continue to be binding constraints for trade.

\footnotetext{
2 The countries of Eurasia refer to the post-Soviet Union states excluding the Baltic states. This includes: Armenia, Azerbaijan, Belarus, Georgia, Kazakhstan, Kyrgyzstan, Moldova, Russia, Tajikistan, Turkmenistan, Ukraine, and Uzbekistan.
} 
Figure 2

Eurasia's Exports by Product
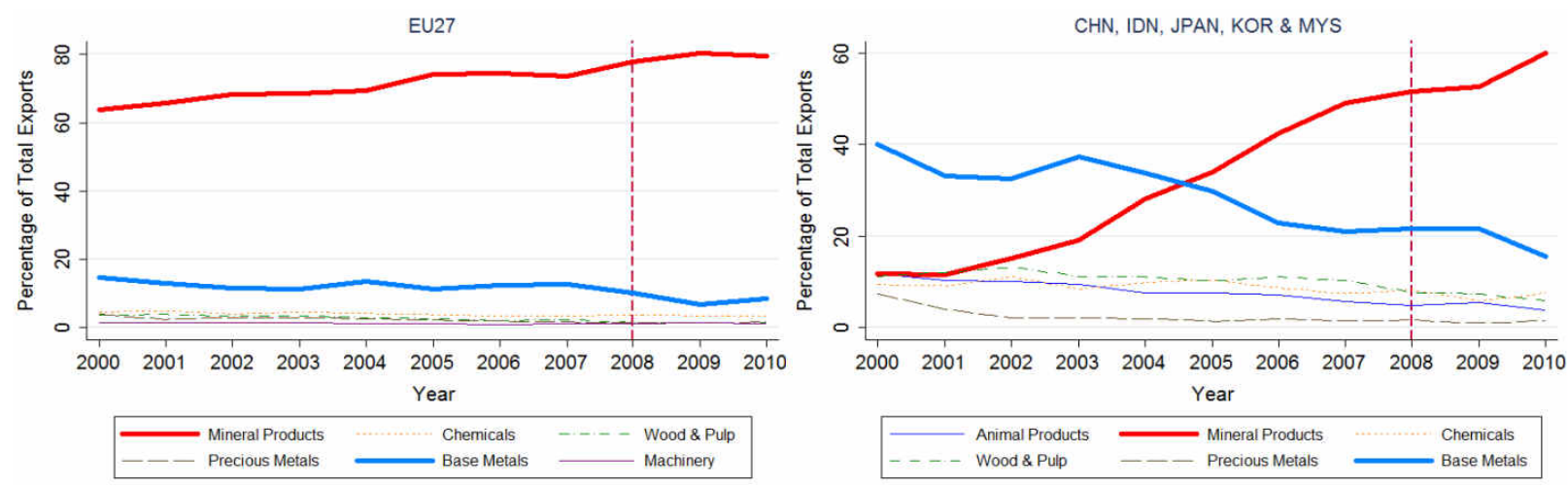

Figure 2 presents product shares of Eurasia's exports to the EU and Asian countries between 2000 and 2010.

Source: Authors' calculations using data from UN Comtrade accessed through WITS (2012).

To shed light on this observation, this document analyzes trade policy barriers in Eurasia, EAP, and the EU. The objective is to identify obstacles to trade diversification by exploring the role of tariffs, non-tariff measures, temporary trade barriers, trade agreements, and regulatory barriers in services trade across export destinations. Several conclusions can be drawn from the analysis.

First, China, Korea, and Japan, as well as the European Union, impose high levels of protection on products of animal origin, and low levels of protection on raw materials such as petroleum oils, iron ores, and minerals. This result may explain the lack of Eurasian product diversification toward the East Asia and the Pacific and the European Union regions. It also highlights the potential benefits of diversifying the structure of production in Eurasia toward more sophisticated and technologically intensive goods that are neither food nor petroleum, and are less exposed to the effects of trade protection.

Second, the EAP region (especially China) appears to be more protectionist than the EU, suggesting a greater challenge for Eurasian countries in diversifying exports to the destination. While Eurasia shows virtually open trade regimes in services with minor restrictions, Eurasia's trading partners considered in this note tend to have intermediate levels of restrictiveness. Compliance costs of NTMs can erode competitive advantages of developing countries, and NTMs are found to be economically important trade barriers in destination countries for a number of products exported by Eurasian economies. While the EU applies technical barriers to trade and antidumping measures against Eurasian exports, some EAP countries and in particular China apply many different types of NTMs (with the exception of pre-shipment inspections) across a range of products.

And third, few or no regional trade agreements exist between Eurasian countries and countries in the EU or EAP. The inability to effectively implement RTAs within the Eurasian region and the limited scope of RTAs outside of Eurasia suggest that multilateralism through WTO accession would have considerable benefits, as multilateral initiates could erode such preference margins.

The paper is structured as follows. Section 1 studies tariffs; Section 2 analyzes non-tariff measures (NTMs); Section 3 examines temporary trade barriers (TTBs); Section 4 discusses the role of trade agreements; Section 5 deals with trade barriers in services; and the final section presents the main conclusions. 


\section{TARIFFS}

\subsection{Tariffs in Eurasian Countries}

Despite recent reductions in tariffs, these trade policy barriers continue to be binding constraints that prevent the international exchange of products. The highest tariffs in the Eurasian region are imposed by Russia, Belarus, and Kazakhstan, which form a customs union. By 2010, none of these countries was a World Trade Organization (WTO) member (although Russia has since become the $156^{\text {th }}$ member of the WTO in August 2012), therefore we focus the analysis on the simple average applied tariff including preferences (instead of the most favored nation (MFN) tariff), which varies between $6.012 \%$ for Russia and $6.778 \%$ for Belarus (Table 1 ). ${ }^{3}$ The MFN tariff is the border (import) tax rate that one WTO member imposes on imports from another WTO member, unless the country is part of a preferential trade agreement (PTA). The MFN tariff is calculated as a simple and weighted average of the rates available at each product-destination combination. The weights are the share of imports on total imports. The average applied tariff including preferences is the effectively applied tariff. To conduct the analysis, we employ data from UNCTAD and the WTO accessed through the World Bank's World Integrated Trade Solution (WITS).

The highest level of protection imposed by Russia, Belarus, and Kazakhstan is observed in the sector of motor vehicles for the transport of goods. The import duties corresponding to the products that belong to this category range from 22.5\% (HS 870423) to 25\% (HS 870422). The weighted average applied tariff ranges between 2.241\% for Belarus and 3.728\% for Russia. The difference between the simple and the weighted average applied tariff is explained by the particular import structure of the country. The lower weighted average applied tariff for Russia is the result of imports of medicaments, the most important category, which accounts for 3.07\% of total imports, and has tariffs that vary between $0 \%$ and $10 \%$, depending on the trading partner. Motor cars and motor vehicles is the second most important category, representing $2.67 \%$ of total imports, and having no tariff. Electrical apparatus for line telephony or line telegraphy, the category that explains $1.67 \%$ of total imports, has tariffs that vary between $0 \%$ and $5 \%$. Belarus's imports are concentrated in petroleum oils and natural gas, which account for $32.65 \%$ of total imports. The tariffs for these products range from $0 \%$ to $5 \%$. Kazakhstan's leading imports correspond to tubes and pipes $(5.42 \%)$ and petroleum oils $(5.0 \%)$. The tariffs for these goods vary between $0 \%$ and $13 \%$, and $0 \%$ and $5 \%$, respectively.

Table 1

MFN Applied Tariff and Applied Tariff Including Preferences

\begin{tabular}{lcccc}
\hline \hline \multirow{2}{*}{ Country } & \multicolumn{2}{c}{ Applied including preferences } & \multicolumn{2}{c}{ MFN applied } \\
\cline { 2 - 4 } & \multicolumn{1}{c}{ Simple average (\%) } & Weighted average (\%) & Simple average (\%) & Weighted average (\%) \\
\hline Russian Federation & 6.012 & 3.728 & n.wto & n.wto \\
Belarus & 6.778 & 2.241 & n.wto & n.wto $^{\mathrm{a}}$ \\
Georgia & 0.495 & 0.387 & 0.687 & 1.139 \\
Kazakhstan & 6.482 & 3.550 & n.wto & n.wto \\
Tajikistan & 4.355 & 5.861 & n.wto & n.wto \\
Kyrgyz Republic & 3.237 & 2.292 & 3.948 & 4.335 \\
Moldova & 4.564 & 2.396 & 5.107 & 3.397 \\
\hline
\end{tabular}

non-WTO member in 2010.

Source: Authors' calculations using data from UNCTAD accessed through WITS (2012).

Technically, the simple average applied tariff including preferences should be the same for Russia, Belarus, and Kazakhstan as these countries form a customs union. Differences are explained by the presence of missing values for some product lines. 
Georgia, Kyrgyzstan, and Moldova are WTO members and have lower tariffs than Russia, Belarus, and Kazakhstan. The simple average MFN applied tariff varies between $0.687 \%$ for Georgia, the country with many of the lowest trade policy barriers of the region, and $5.107 \%$ for Moldova. The highest level of protection in Georgia corresponds to products such as wheat or meslin flour, cigarettes, and cane or beet sugar, which face an MFN applied tariff of $12 \%$. In Kyrgyzstan, import duties are high for goods like cane or beet sugar and tomatoes prepared or preserved, which have tariffs of $25 \%$ and $20 \%$, respectively. Moldova's protection is concentrated on cane or beet sugar and peas, with tariffs of $30 \%$ and $25 \%$, respectively. Imports from these countries are mainly concentrated in petroleum oils and natural gas, which are duty-free. The simple average applied tariff including preferences varies between $0.495 \%$ for Georgia and $4.564 \%$ for Moldova.

The Trade Tariff Restrictive Index (TTRI) and the Overall Trade Restrictiveness Index (OTRI) also provide valuable information on trade protection. The first index measures the equivalent uniform tariff of a country's tariff schedule that would keep domestic import levels constant, and is calculated using applied tariffs including preferences. The second index is the same as the TTRI but also takes into account NTMs. ${ }^{4}$ Table 2 presents the value and ranking corresponding to the indicators, which are calculated as simple averages of the values observed in the 2006-2009 period. The TTRI varies between $2.05 \%$ for Kazakhstan and $8.81 \%$ for Belarus. According to this measure, the region presents intermediate to high levels of protection as countries' rankings vary between the $39^{\text {th }}$ and $93^{\text {rd }}$ positions, out of 125 countries. The higher values of OTRIs compared to TTRIs indicate that NTMs are also economically important trade barriers for a number of imported products. In particular, the uniform tariff ranges from $5.1 \%$ for Moldova to $18.99 \%$ for Russia. If we compare the TTRI and the OTRI rankings, we observe that Moldova and Belarus have better positions in the latter, showing that NTMs are less restrictive. In contrast, the rest of the economies are located in lower positions of the ranking.

Table 2

Trade Tariff Restrictiveness Index and Overall Trade Restrictiveness Index

\begin{tabular}{|c|c|c|c|c|}
\hline \multirow{2}{*}{ Country } & \multicolumn{2}{|c|}{ TTRI } & \multicolumn{2}{|c|}{ OTRI } \\
\hline & Value & $\operatorname{Rank}^{\mathbf{a}}$ & Value & $\operatorname{Rank}^{b}$ \\
\hline Moldova & 2.6 & 41 & 5.1 & 11 \\
\hline Kazakhstan & 2.05 & 39 & 12.42 & 65 \\
\hline Belarus & 8.81 & 93 & 16.88 & 73 \\
\hline Ukraine & 4.2 & 56 & 18.8 & 80 \\
\hline Russian Federation & 5.51 & 73 & 18.99 & 82 \\
\hline Azerbaijan & 5.3 & 71 &.$^{\mathrm{c}}$ &.$^{c}$ \\
\hline Kyrgyz Republic & 3.5 & 50 &.$^{c}$ & $\mathrm{c}$ \\
\hline
\end{tabular}

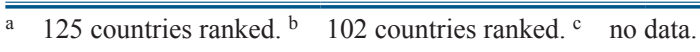

Source: World Bank's World Trade Indicators (2012).

The last two indicators - tariff bound lines and total overhang - provide information on the security of a country's legal commitments to its current trade policy. The share of bound tariff lines measures the share of lines in a country's tariff schedule subject to WTO negotiation agreements. The bound rate is the highest rate of duty allowed to be levied on a product under the

4 NTMs represent another type of trade policy barrier. NTMs are broadly distinguished in sanitary and phytosanitary standards (SPS) measures, technical barriers to trade (TBTs), quantitative controls, pre-shipment inspections, and price controls. SPS measures and TBTs are the most common forms through which NTMs materialize. 
GATT/WTO agreement. Thus, the bound is a legal commitment above which a country promises not to raise the MFN applied tariff. Total overhang measures the difference between the average bound rates and the average MFN applied rates at the 6-digit Harmonized System tariff line level in a country's customs schedule. It is equivalent to subtracting the average of all MFN applied rates from the average of all bound rates for each country. Table 3 presents the indicators.

Countries such as Armenia, Georgia, Moldova, and Ukraine have bound 100\% of their tariff lines at the WTO, and therefore they are located at $1^{\text {st }}$ position in the ranking. In contrast, nations such as Tajikistan and Uzbekistan do not bound any tariff lines as they are not WTO members. The total overhang ranges from 1.26 percentage points for Ukraine to 6.12 percentage points for Georgia. The countries' rankings vary between the $36^{\text {th }}$ and $52^{\text {nd }}$ positions.

Table 3

Tariff Bound Lines and Total Overhang

\begin{tabular}{|c|c|c|c|c|}
\hline \multirow{2}{*}{ Country } & \multicolumn{2}{|c|}{ Share of tariff bound lines (\%) } & \multicolumn{2}{|c|}{ Total overhang (\%) } \\
\hline & Value & $\operatorname{Rank}^{\mathbf{a}}$ & Value & $\operatorname{Rank}^{\mathbf{b}}$ \\
\hline Armenia & 100 & 1 & 5.25 & 49 \\
\hline Georgia & 100 & 1 & 6.12 & 52 \\
\hline Moldova & 100 & 1 & 2.26 & 40 \\
\hline Ukraine & 100 & 1 & 1.26 & 36 \\
\hline Kyrgyz Republic & 99.9 & 83 & 2.87 & 41 \\
\hline Tajikistan & 0 & 152 &.${ }^{\mathrm{c}}$ &.$^{c}$ \\
\hline Uzbekistan & 0 & 152 &.$^{\mathrm{c}}$ & $\mathrm{c}^{\mathrm{c}}$ \\
\hline
\end{tabular}

a 164 countries ranked. $^{\mathrm{b}} 150$ countries ranked. $^{\mathrm{c}}$ no data.

Source: World Bank's World Trade Indicators (2012).

\subsection{Tariffs in East Asia and the Pacific and the European Union}

Tariffs in EAP seem to be, with the exception of Japan, higher than in Eurasian countries. China's simple average MFN tariff is $9.289 \%$ and Korea's is $10.284 \%$ (Table 4). The highest level of protection in China is observed in products such as rice, barley, wheat, or meslin flour, with tariffs of $65 \%$. Trade barriers in products that are imported from Eurasian countries, i.e., petroleum oils and oils obtained from bituminous minerals, raw hides and skins, and iron ores and concentrates, are minor. In the majority of the cases, these products have no import duty. Korea's protection is concentrated in buckwheat, millet, and canary seed (tariffs of $800.3 \%$ ), starches and inulin (tariffs of 747\%), and manioc, arrowroot, salep, and sweet potatoes (tariffs of $630 \%$ ).

Indonesia shows intermediate levels of protection as its applied MFN tariff is $6.87 \%$. The country's tariff barriers are mainly focused on goods like mixtures of odoriferous substances, cigars, and motor vehicles principally designed for the transport of persons, which have tariffs of $101.67 \%, 40 \%$, and $40 \%$, respectively. Similar to China and Korea, imports of petroleum and semi-finished products of iron or non-alloy steel, which come from Eurasian economies, are dutyfree. The lowest level of protection is observed in Japan, with an applied MFN tariff of 3.24\%. Trade policy barriers are high in products such as sugars (tariffs of 43.27\%), and cheese and curd (tariffs of 40\%). Eurasia's exports to Japan, mainly of petroleum and unwrought aluminum, pay tariffs that do not exceed $1.32 \%$. The effectively applied tariffs are, by definition, lower than the MFN applied tariffs as a result of PTAs. Concessions related to PTAs seem to be relatively more important in Indonesia and China. 
Table 4

MFN Applied Tariff and Applied Tariff Including Preferences

\begin{tabular}{lcccc}
\hline \multirow{2}{*}{ Country } & \multicolumn{2}{c}{ Applied including preferences } & \multicolumn{2}{c}{ MFN applied } \\
\cline { 2 - 5 } & \multicolumn{1}{c}{ Simple average (\%) } & Weighted average (\%) & Simple average (\%) & Weighted average (\%) \\
\hline China & 7.649 & 3.469 & 9.289 & 4.089 \\
Indonesia & 4.742 & 2.358 & 6.876 & 5.193 \\
Japon & 2.534 & 1.511 & 3.204 & 1.833 \\
Korea & 10.084 & 7.832 & 10.284 & 7.949 \\
\hline
\end{tabular}

Source: Authors' calculations using data from UNCTAD accessed through WITS (2012).

The TTRI and OTRI show intermediate levels of protection in relative terms for China, Indonesia, and Malaysia. The equivalent uniform tariffs excluding NTMs are 5.06\%, 4.47\%, and $3.01 \%$, respectively, ranking the countries in positions $68^{\text {th }}, 62^{\text {nd }}$, and $45^{\text {th }}$ (out of 125 countries), respectively. If we compare the TTRI with the OTRI rates, we observe that the latter are larger than the former, highlighting the fact that NTMs are important. For example, China's equivalent uniform tariff increases from $5.06 \%$ to $9.83 \%$ when considering NTMs. The increment is lower in Indonesia, of 3 percentage points, from $4.47 \%$ to $7.47 \%$. In Malaysia, the uniform tariff increases from $3.01 \%$ to $23.8 \%$ when considering NTMs.

China has bound $100 \%$ of its tariff lines at the WTO, while Indonesia and Malaysia have bound $96.6 \%$ and $83.7 \%$ of their products, respectively. The total overhang shows that there is room to increase the MFN applied tariffs in Malaysia and Indonesia. The binding rates are 60.06 and 30.42 percentage points, respectively, higher than the applied MFN rates. In contrast, China has no overhang.

The levels of protection in the EU are lower than the ones observed in EAP. The simple average MFN applied tariff is $4.263 \%$ and the weighted average is $2.514 \%$. Trade policy barriers are high in products such as tobacco and cigars, which have tariffs of $74.9 \%$ and $57.6 \%$, respectively. However, imports from Eurasian countries are concentrated in petroleum oils and unwrought nickel, for which trade policy barriers are almost negligible. The TTRI and OTRI indexes show low levels of protection since the EU is ranked in positions $11^{\text {th }}$ and $16^{\text {th }}$, respectively, with equivalent uniform tariffs of $1.79 \%$ and $6.38 \%$, respectively. The countries have bound $100 \%$ of their tariff lines at the WTO, and have a total overhang of 0.04 percentage points.

An analysis of the tariff structures of China, Korea, Japan, and the EU suggests that these countries impose higher levels of protection for products such as live animals, meat \& edible meat, fish, dairy products, products of animal origin, to mention a few (Table 5). This is an interesting fact that highlights the benefits of diversifying the production to more sophisticated and technologically intensive goods, which are less exposed to the effects of trade protection. To analyze the implications of protection for Eurasian countries, we incorporate the export structure of these economies into the analysis. In particular, we calculate the average tariff that exports from the region will have to pay. ${ }^{5}$ The tariff is a weighted average of the import duties applied to each 6-digit Harmonized System product category. The weights represent the share of a country's total exports to the world of a product on total exports to the world of a group of products that includes the good. To conduct the analysis, we classify products into three groups: i) live animal, meat \& edible meat, fish, dairy products, products of animal origin, live tree $\&$ other plants, and edible vegetables \& fruits; ii) petroleum; and iii) the remaining products. ${ }^{6}$ Table 5 presents the results of

To conduct the analysis, we employ MFN tariffs in the case when the exporter is a WTO member and non-MFN tariffs otherwise.

The Harmonized System tariff lines corresponding to group i) are HS 01-08 and to group ii) are HS 2709-2719. 
the average tariffs applied by the EU and EAP countries on exports of Eurasian countries. Data on tariffs is available at 6 digits. ${ }^{7}$

Table 5

Export Weighted Average Tariffs

\begin{tabular}{|c|c|c|c|c|c|c|c|c|c|c|c|c|}
\hline \multirow{2}{*}{ Country } & \multicolumn{4}{|c|}{ China } & \multicolumn{4}{|c|}{ Indonesia } & \multicolumn{4}{|c|}{ Japan } \\
\hline & Total & Sector 1 & Sector2 & Sector 3 & Total & Sector 1 & Sector2 & Sector3 & Total & Sector 1 & ector2 & Sector3 \\
\hline Russia & 3.17 & 10.59 & 1.66 & 7.09 & 2.07 & 6.19 & 1.22 & 4.27 & 0.99 & 6.08 & 0.94 & 1.07 \\
\hline Belarus & 33.91 & 72.97 & 20.35 & 39.84 & 4.70 & 5.40 & 0.74 & 6.72 & 1.77 & 16.94 & 1.01 & 1.92 \\
\hline Georgia & 4.13 & 12.04 & 3.58 & 3.74 & 2.05 & 7.52 & 0.47 & 2.56 & 1.57 & 7.54 & 0.54 & 1.63 \\
\hline Kazakhstan & 10.31 & 67.13 & 24.20 & 27.13 & 1.15 & 8.09 & 0.27 & 3.13 & 0.48 & 5.65 & 0.10 & 1.28 \\
\hline Tajikistan & 42.79 & 69.26 & 19.75 & 38.00 & 1.99 & 6.03 & 4.88 & 1.10 & 2.58 & 9.81 & 0.35 & 1.17 \\
\hline Kyrgyz & 10.77 & 12.12 & 4.52 & 10.98 & 7.10 & 5.19 & 0.37 & 7.93 & 4.14 & 5.14 & 0.68 & 3.94 \\
\hline Moldova & 13.03 & 14.16 & 0.98 & 13.07 & 7.72 & 5.32 & 0.22 & 9.40 & 6.77 & 10.74 & 0.67 & 6.73 \\
\hline Uzbekistan & 66.67 & 68.49 & 20.39 & 78.23 & 6.10 & 4.92 & 4.19 & 6.74 & 1.87 & 6.81 & 0.64 & 1.62 \\
\hline Turkmenistan & 35.22 & 84.22 & 19.74 & 76.62 & 3.99 & 5.00 & 3.16 & 6.10 & 2.91 & 5.80 & 3.08 & 2.92 \\
\hline Azerbaijan & 3.29 & 77.46 & 22.51 & 53.19 & 0.31 & 6.73 & 0.07 & 6.41 & 0.28 & 9.90 & 0.06 & 4.42 \\
\hline Armenia & 6.18 & 8.22 & 0.45 & 6.10 & 5.28 & 3.86 & 5.00 & 6.28 & 2.43 & 2.45 & 3.92 & 2.42 \\
\hline Ukraine & 7.76 & 14.39 & 4.02 & 8.07 & 4.13 & 5.00 & 1.45 & 4.47 & 1.60 & 13.82 & 0.70 & 1.54 \\
\hline \multirow{2}{*}{ Country } & \multicolumn{4}{|c|}{ Korea } & \multicolumn{4}{|c|}{ Malaysia } & \multicolumn{4}{|c|}{$\mathbf{E U}$} \\
\hline & Total & Sector 1 & Sector2 & Sector3 & Total & Sector 1 & Sector2 & Sector3 & Total & Sector 1 & Sector2 & Sector3 \\
\hline Russia & 3.63 & 17.97 & 3.09 & 4.73 & 2.67 & 0.41 & 1.31 & 6.48 & 1.20 & 10.02 & 0.75 & 2.21 \\
\hline Belarus & 5.28 & 74.92 & 4.27 & 4.57 & 4.84 & 1.38 & 0.18 & 7.17 & 2.25 & 10.69 & 2.58 & 2.05 \\
\hline Georgia & 6.58 & 49.97 & 3.74 & 4.36 & 1.92 & 2.46 & 0.92 & 2.54 & 2.67 & 6.37 & 1.63 & 2.93 \\
\hline Kazakhstan & 3.17 & 29.71 & 3.05 & 3.09 & 2.46 & 1.25 & 2.22 & 3.06 & 0.61 & 12.20 & 0.21 & 1.44 \\
\hline Tajikistan & 12.18 & 57.33 & 1.17 & 3.31 & 1.70 & 3.75 & 0.00 & 1.33 & 3.72 & 8.26 & 0.01 & 2.92 \\
\hline Kyrgyz & 17.21 & 58.49 & 4.00 & 5.97 & 6.33 & 3.20 & 0.66 & 7.47 & 5.24 & 8.73 & 2.08 & 4.83 \\
\hline Moldova & 25.30 & 49.17 & 4.82 & 22.49 & 8.18 & 2.95 & 0.02 & 10.32 & 7.50 & 7.52 & 0.34 & 8.09 \\
\hline Uzbekistan & 10.74 & 79.32 & 1.79 & 5.03 & 4.48 & 4.80 & 0.04 & 5.68 & 2.83 & 8.70 & 0.43 & 2.90 \\
\hline Turkmenistan & 3.47 & 37.04 & 2.83 & 5.01 & 1.93 & 2.41 & 0.18 & 6.36 & 1.75 & 6.99 & 0.94 & 3.77 \\
\hline Azerbaijan & 4.31 & 109.94 & 3.05 & 8.35 & 2.61 & 7.41 & 2.39 & 8.48 & 0.25 & 7.56 & 0.09 & 3.41 \\
\hline Armenia & 7.40 & 19.40 & 2.17 & 6.68 & 4.74 & 1.83 & 0.00 & 5.85 & 2.97 & 4.94 & 0.02 & 2.90 \\
\hline Ukraine & 18.27 & 47.18 & 3.44 & 19.46 & 7.70 & 1.16 & 0.26 & 8.83 & 2.18 & 7.81 & 1.63 & 2.23 \\
\hline
\end{tabular}

Source: Authors' calculations using tariff data from UNCTAD and trade data from UN Comtrade accessed through WITS (2012).

The ideal situation would be to have information on MFN and non-MFN tariffs for all the trading partners. However, WITS presents information on non-MFN tariffs only for China and Japan. Therefore, to conduct the analysis, we employ, when possible, information on MFN and non-MFN tariffs. Otherwise, we assume that countries impose the MFN tariffs to all the nations independently of their affiliation to the WTO. This is a limitation, and one should be aware of the fact that the levels of protection faced by non-WTO members could be higher than the ones displayed in the analysis. In cases where information on tariffs is not available at 6-digits, we employ averages at 4-digits. 
If we consider the case of China, we observe that countries such as Turkmenistan, Azerbaijan, and Belarus face the highest levels of protection (see Appendix). In the case of Turkmenistan, exports of guts, bladders, and stomachs of animals, which represent $34.1 \%$ of the exports of group 1, have a tariff of $88.57 \%$. Trade policy barriers faced by Azerbaijan are associated to tariffs of $70 \%$ on hazelnuts, tomatoes, and potatoes, which account for $40 \%$ of the exports of group 1. Belarus's average tariff, $72.9 \%$, reflects trade protection on exports of truffles (tariff of $75 \%$ ), which explain $27 \%$ of the external sales of food. Tariffs on products that belong to group 3 are lower than that corresponding to group 1, but higher than the tariffs related to petroleum. Uzbekistan and Turkmenistan are the countries that face a higher level of protection. In both cases, exports of cotton, not carded or combed, mostly explain the average tariffs of $78.23 \%$ and $76.62 \%$, respectively. Exports of petroleum are associated to tariffs of $20 \%$, approximately, for most of the non-WTO members.

The conclusions regarding Korea's level of protection are similar to the ones drawn from China. However, contrary to the case of China, trade policy barriers do not seem to generate substantial differences between the average tariffs applied to products that belong to group 2 and those imposed on group 3. This fact is important, as it suggests the potential benefits of diversifying towards goods that are neither food nor petroleum. Countries such as Azerbaijan, Uzbekistan, and Belarus face average tariffs in food that exceed $74 \%$ (see Appendix). In the case of Azerbaijan, tariffs on potatoes, fresh or chilled (304\%), and those on tomatoes, fresh or chilled (45\%), explain the high level of protection, accounting for $21 \%$ of the exports of group 1. Moldova is the country with the highest level of protection in products that belong to the third category, with goods such as sunflower seeds and wine paying tariffs of $25 \%$ and $15 \%$, respectively. Tariffs on petroleum do not exceed $5 \%$.

The EU's tariff scheme displays the same pattern as the one observed for China and Korea. That is, trade protection is biased against food products. The export structure of Eurasian countries shows that Belarus and Kazakhstan are the countries that face the highest levels of protection, with average tariffs of $10.69 \%$ and $12.20 \%$, respectively (see Appendix). In the case of Belarus, exports of truffles, fresh or chilled, which account for $33.24 \%$ of the exports of group 1 , have an import duty of $11.55 \%$. The results for Kazakhstan are mainly driven by exports of frozen fish fillets $(53.9 \%$ of the total exports of group 1), which pay a tariff of $15 \%$. Average tariffs for category 3 vary between $1.44 \%$ for Kazakhstan and $8.09 \%$ for Moldova. The latter tariff is mainly explained by exports of wine, which represent $5.6 \%$ of the exports of group 3, and have a tariff of $32 \%$. Average tariffs corresponding to petroleum are, for the majority of the countries, lower than the rest of the tariffs. They vary between $0.02 \%$ for Armenia and $2.58 \%$ for Belarus.

Tariff barriers in Japan present similar characteristics to those in China, Korea, and the EU. However, differences between MFN and non-MFN tariffs are lower than in China. The protectionist bias against food is important in cases such as Belarus and Ukraine (see Appendix). Average tariffs corresponding to group 1 are 15.01 and 12.28 percentage points higher than those associated to group 3, respectively. In the case of Belarus, the tariffs related to the main four products of group 1 vary between $5.16 \%$ for truffles and $35 \%$ for butter and other fats. The barriers that Ukraine faces are explained by import duties of $14.9 \%$ on cheese, which account for $40.2 \%$ of its exports. The levels of protection for group 3 range from $1.07 \%$ for Russia to $6.73 \%$ for Moldova. In the last case, exports are quite dispersed across different product categories. The result is driven by tariffs of $15 \%$ on products such as wine.

The case of Indonesia is interesting because protection seems to be larger for non-food and non-petroleum products. Countries such as Moldova and Kyrgyzstan face differences of 4.08 and 2.74 percentage points between the average tariffs applied on goods that belong to group 3 and those imposed on products of group 1, respectively (see Appendix). Bars and rods, the most important products of group 3 in Moldova, face tariffs of 7.1\%. In Kyrgyzstan, exports of natural uranium and its compounds, which represent $36.8 \%$ of the exports of group 3, pay an import duty 
of 5\%. Men's or boys' trousers and women's or girls' blouses (9.5\% of exports of group 3) face tariffs of $15 \%$. Tariffs on petroleum range from $0.07 \%$ for Azerbaijan to $5 \%$ for Armenia.

Malaysia appears to be the least protectionist country. Similar to Indonesia, the tariff structure reflects higher trade barriers for goods that are neither food nor petroleum. Countries such as Moldova pay an average tariff of $10.32 \%$ as a result of import duties of $15 \%$ on bars and rods (5.8\% of the exports) and $21.7 \%$ on ignition wiring sets (3.5\% of the exports) (see Appendix). Azerbaijan also faces higher levels of protection compared with other countries. The average tariff of $8.48 \%$ corresponds to exports of polyethylene ( $9 \%$ of the exports), and U sections, not further worked than hot-rolled, hot-drawn or extruded, of a height of $80 \mathrm{~mm}$ (7\% of the exports). Both products have import duties of $20 \%$. Average tariffs for food vary between $0.41 \%$ for Russia and $7.41 \%$ for Azerbaijan. The last result is due to exports of some fruits (41\%), which pay an import duty of $16.25 \%$. Burdens on petroleum are lower than $2.4 \%$.

\section{NON-TARIFF MEASURES}

NTMs represent another type of trade policy barrier. NTMs are broadly distinguished into technical measures, including sanitary and phytosanitary standards (SPS) measures and technical barriers to trade (TBTs), and non-technical barriers. The latter are distinguished into quantitative controls, pre-shipment inspections, and price control measures. The large incidence of SPS measures and TBTs raise concerns for developing countries' exports. The costs of compliance of SPS measures and TBTs are higher for low-income countries, and can erode the competitive advantage that these nations have in terms of lower labor costs and preferential access (Cadot et al., 2012). Only a small proportion of these NTMs are still in the form of quotas and export restrictions, since most quantitative restrictions are illegal under WTO rules. In the cases where quantitative measures are allowed, they materialize in the form of non-automatic licensing, often necessary to administer the importation of goods where SPS- and TBT-related issues are of particular importance. Pre-shipment inspections are, in many cases, necessary to assure the quality and quantity of a shipment, thus facilitating trade, but they do add to the costs of trading. Price control measures are one of the least used forms of NTMs. These barriers affect only a small share of goods and are largely related to anti-dumping and countervailing duties, as well as some forms of administrative pricing for staple food and energy or other sensitive products.

NTMs can have different effects on trade. "On the one hand, requirements on marking, labeling, and packaging, although adding to costs of production, generally are not discriminatory. On the other hand, quotas, voluntary export restraints, and non-automatic import authorizations often have much more significant effects" (Gourdon and Nicita, 2012). To analyze the extent to which NTMs constitute an important barrier to trade, we use the indicators constructed by Gourdon and Nicita (2012), which employ a newly collected dataset on NTMs constructed by the World Bank, the International Trade Center, and UNCTAD. The analysis relies on two indicators: the frequency and coverage ratio of NTMs. The frequency ratio accounts only for the presence or absence of an NTM, and summarizes the percentage of products to which one or more NTMs are applied. In more formal terms, the index for country $j$ is calculated as follows:

$$
F_{j}=\left[\frac{\sum D_{i} M_{i}}{\sum M_{i}}\right] 100
$$

where $D$ is a dummy variable reflecting the presence of one or more NTMs affecting product $i$, and $M$ indicates whether country imports good $i$ (also a dummy variable). To capture the relative value of the affected products, we use the coverage ratio. In formal terms, the measure is given by: 


$$
C_{j}=\left[\frac{\sum V_{i} D_{i}}{\sum V_{i}}\right] 100
$$

where $D$ is defined as before, and is the value of country's imports of product $i$. Table 6 presents the results.

Table 6

NTMs: Frequency and Coverage Ratio

\begin{tabular}{lcc}
\hline \multicolumn{1}{c}{ Country } & Frequency & Coverage ratio \\
\hline China & $100 \%$ & $100 \%$ \\
European Union & $90.1 \%$ & $86.2 \%$ \\
Indonesia & $43.5 \%$ & $36.8 \%$ \\
Japan & $39.4 \%$ & $59.5 \%$ \\
\hline \hline
\end{tabular}

Source: Gourdon and Nicita (2012) and authors' calculations for China using data from UNCTAD accessed through WITS (2012).

It is important to acknowledge that this analysis assumes that all NTMs are applied on a nondiscriminatory basis. This implies that if a country applied a particular NTM to the imports of a product from a single country, it will do the same with the imports of the same product from all countries.

China imposes at least one NTM in $100 \%$ of the about 5,000 products at the HS 6-digit classification level, followed in incidence by the EU (90.1\%), while Indonesia and Japan have less than $50 \%$ of the product lines affected by these types of measures. The coverage ratios show high levels of protection in China (100\%) and the EU (86.2\%).

To conduct the analysis at the sectoral level, we group NTMs into nine categories: A: SPS measures; B: TBTs; C: Pre-shipment inspection and other formalities; D: price control measures; $\mathrm{E}$ : licenses, quotas, prohibitions, and other quantity control measures; F: charges, taxes, and other para-tariff measures; $\mathrm{H}$ : anti-competitive measures; $\mathrm{N}$ : intellectual property; and $\mathrm{P}$ : export related measures. Tables 7-10 present frequency ratios.

The study reveals that China applies SPS measures, TBTs, price control measures, and quantitative controls to $100 \%$ of its products in sectors such as food; chemical; rubber, plastics, wood \& paper; textile \& footwear; base metal; and machine \& equipment (Table 7).

Table 7

NTMs in China

\begin{tabular}{|c|c|c|c|c|c|c|}
\hline $\begin{array}{c}\text { NTM } \\
\text { category }\end{array}$ & Food & Chemicals & $\begin{array}{c}\text { Rubber, } \\
\text { plastics, wood, } \\
\text { paper }\end{array}$ & $\begin{array}{l}\text { Textile \& } \\
\text { footwear }\end{array}$ & Base metals & $\begin{array}{c}\text { Machinery \& } \\
\text { equipment }\end{array}$ \\
\hline A & $100 \%$ & $100 \%$ & $100 \%$ & $100 \%$ & $100 \%$ & $100 \%$ \\
\hline B & $100 \%$ & $100 \%$ & $100 \%$ & $100 \%$ & $100 \%$ & $100 \%$ \\
\hline $\mathrm{C}$ & $0 \%$ & $0 \%$ & $2 \%$ & $0 \%$ & $2 \%$ & $78 \%$ \\
\hline D & $100 \%$ & $100 \%$ & $100 \%$ & $100 \%$ & $100 \%$ & $100 \%$ \\
\hline $\mathrm{E}$ & $100 \%$ & $100 \%$ & $100 \%$ & $100 \%$ & $100 \%$ & $100 \%$ \\
\hline
\end{tabular}

Source: Authors' calculations using data from UNCTAD accessed through WITS (2012).

In the EU, most of the NTMs are SPS measures or TBTs (Table 8). In particular, $86.7 \%$ of the product lines associated to food are affected by SPS measures, while $85.4 \%$ of them have 
at least one TBT. For the rest of the sectors, TBTs are the most common measure. For example, more than $90 \%$ of the product lines corresponding to chemical, textile $\&$ footwear, and machine $\&$ equipment have at least one TBT. The rubber, plastics, wood \& paper sector has the lowest percentage of products affected, $60.7 \%$. Pre-shipment inspections are relatively important in the base metal and textile \& footwear sectors, affecting $15.9 \%$ of the product lines in each of these categories.

Table 8

NTMs in the European Union

\begin{tabular}{ccccccc}
\hline \hline $\begin{array}{c}\text { NTM } \\
\text { category }\end{array}$ & Food & Chemicals & $\begin{array}{c}\text { Rubber, } \\
\text { plastics, wood, } \\
\text { paper }\end{array}$ & $\begin{array}{c}\text { Textile \& } \\
\text { footwear }\end{array}$ & Base metals & $\begin{array}{c}\text { Machinery \& } \\
\text { equipment }\end{array}$ \\
\hline $\mathrm{A}$ & $86.7 \%$ & $2.5 \%$ & $5.6 \%$ & $1.9 \%$ & $5.1 \%$ & $6.4 \%$ \\
$\mathrm{~B}$ & $85.4 \%$ & $92.4 \%$ & $60.7 \%$ & $90.6 \%$ & $86.3 \%$ & $91.0 \%$ \\
$\mathrm{C}$ & $3.2 \%$ & $1.7 \%$ & $0.9 \%$ & $15.9 \%$ & $15.9 \%$ & $0.3 \%$ \\
$\mathrm{D}$ & $0.0 \%$ & $0.0 \%$ & $0.0 \%$ & $0.0 \%$ & $0.0 \%$ & $0.0 \%$ \\
$\mathrm{E}$ & $0.0 \%$ & $0.0 \%$ & $0.0 \%$ & $0.0 \%$ & $0.0 \%$ & $0.0 \%$ \\
\hline \hline
\end{tabular}

Source: Gourdon and Nicita (2012).

Indonesia applies different categories of NTMs depending on the sector (Table 9). Contrary to what is observed in the case of the EU, there is not a particular type of NTM that predominates. Most of the NTMs in the food sector are SPS measures, TBTs, and pre-shipment inspections, which affect $67.9 \%, 33.5 \%$, and $12.8 \%$ of product lines, respectively. The textile $\&$ footwear sector has $63.4 \%$ of its products affected by pre-shipment inspections and $65.8 \%$ by quantitative controls. More than half of the about 813 product lines in the chemical category are affected by TBTs. Machine \& equipment and base metal are the sectors with lower barriers. In both cases, quantitative controls are the category of NTMs most commonly applied, $14.3 \%$ and $26.3 \%$, respectively.

Table 9

NTMs in Indonesia

\begin{tabular}{|c|c|c|c|c|c|c|}
\hline $\begin{array}{c}\text { NTM } \\
\text { category }\end{array}$ & Food & Chemicals & $\begin{array}{c}\text { Rubber, } \\
\text { plastics, wood, } \\
\text { paper }\end{array}$ & $\begin{array}{l}\text { Textile \& } \\
\text { footwear }\end{array}$ & Base metals & $\begin{array}{c}\text { Machinery \& } \\
\text { equipment }\end{array}$ \\
\hline A & $67.9 \%$ & $1.8 \%$ & $18.1 \%$ & $3.6 \%$ & $0.0 \%$ & $0.0 \%$ \\
\hline $\mathrm{B}$ & $33.5 \%$ & $50.7 \%$ & $4.3 \%$ & $17.3 \%$ & $22.1 \%$ & $9.1 \%$ \\
\hline $\mathrm{C}$ & $12.8 \%$ & $2.8 \%$ & $1.9 \%$ & $63.4 \%$ & $5.0 \%$ & $6.4 \%$ \\
\hline $\mathrm{D}$ & $0.0 \%$ & $0.0 \%$ & $0.0 \%$ & $0.0 \%$ & $0.0 \%$ & $0.0 \%$ \\
\hline $\mathrm{E}$ & $2.2 \%$ & $15.3 \%$ & $3.0 \%$ & $65.8 \%$ & $26.3 \%$ & $14.3 \%$ \\
\hline
\end{tabular}

Source: Gourdon and Nicita (2012).

Japan's NTMs are mainly concentrated in two sectors, food and chemical, but the type of NTM employed differs between them (Table 10). The food sector registers $90.6 \%$ of its product lines with an SPS measure, while the chemical sector has $81.9 \%$ of its import lines with a TBT. Protection in the textile \& footwear sector is minor, 3.1\% for TBTs and $2.3 \%$ for SPS measures. TBTs are mainly used in the rubber, plastics, wood \& paper sector, as $39.7 \%$ of the products 
belonging to this category are affected by them. Barriers on the machine \& equipment sector appear mostly in the form of TBTs, affecting $14.2 \%$ of the product lines corresponding to this category.

Table 10

NTMs in Japan

\begin{tabular}{lcccccc}
\hline \hline $\begin{array}{c}\text { NTM cat- } \\
\text { egory }\end{array}$ & Food & Chemicals & $\begin{array}{c}\text { Rubber, plas- } \\
\text { tics, wood, } \\
\text { paper }\end{array}$ & $\begin{array}{c}\text { Textile \& foot- } \\
\text { wear }\end{array}$ & Base metals & $\begin{array}{c}\text { Machinery \& } \\
\text { equipment }\end{array}$ \\
\hline A & $90.6 \%$ & $9.7 \%$ & $17.0 \%$ & $2.3 \%$ & $6.7 \%$ & $7.2 \%$ \\
B & $13.7 \%$ & $81.9 \%$ & $39.7 \%$ & $3.1 \%$ & $3.6 \%$ & $14.2 \%$ \\
C & $0.0 \%$ & $0.0 \%$ & $0.0 \%$ & $0.0 \%$ & $0.0 \%$ & $0.0 \%$ \\
D & $5.5 \%$ & $0.0 \%$ & $0.0 \%$ & $0.0 \%$ & $0.0 \%$ & $0.0 \%$ \\
E & $17.6 \%$ & $0.0 \%$ & $0.2 \%$ & $0.0 \%$ & $0.0 \%$ & $0.0 \%$ \\
\hline \hline
\end{tabular}

Source: Gourdon and Nicita (2012).

To analyze the impact of NTMs on Eurasia's exports, we construct two coverage ratio indicators. The first index for country $j$, destination $d$, NTM-category $c$, and product $i$ is calculated as follows:

$$
C_{j}^{c, d}=\left[\frac{\sum D_{i}^{c, d} X_{j, i}^{d}}{\sum X_{j, i}^{d}}\right] 100
$$

where $C_{i}^{c, d}$ is a dummy variable reflecting the presence of one or more NTMs in category $c$ affecting product $i$ in destination $d$, and $X_{j, i}^{d}$ is the value of exports from country $j$ of product $i$ to destination $d$. The second indicator is calculated as follows:

$$
C_{j}^{c, d}=\left[\frac{\sum D_{i}^{c, d} X_{j, i}^{d}}{\sum X_{j, i}^{w}}\right] 100
$$

where $X_{j, i}^{w}$ is the value of exports from country $j$ of product $i$ to the world $w$. Table 11 presents the results. Column I presents the value of the first index and column II presents the value of the second index.

The analysis for Indonesia shows that technical barriers to trade are one of the most important forms of NTMs that affect Eurasia's exports. Countries such as Belarus, Russia, Tajikistan, Ukraine, and Uzbekistan have more than $50 \%$ of their exports to this destination affected by this type of NTM. Quantitative restrictions such as licenses, quotas, prohibitions, and other quantity control measures are also relevant, affecting exports from Armenia (69\%), Georgia (47\%), Kazakhstan (49\%), Moldova (39\%), and Ukraine (37\%). SPS measures are relevant in Turkmenistan, Uzbekistan, and Kyrgyzstan, with $86 \%, 27 \%$, and $18 \%$ of their exports affected by this policy barrier, respectively. Since Indonesia is not a main destination of Eurasia's exports, the coverage ratios measured with total exports to the world are very low and do not exceed $1 \%$.

Eurasia's exports to China are affected by a large variety of NTMs. However, the percentage of exports to China subjected to these types of measures within each category is lower than in the case of Indonesia. No more than $19 \%$ of the exports to China by each Eurasian country are affected by any one type of NTM. Charges, taxes, and other para-tariff measures are the 
less used form of NTMs. The coverage ratios measured with total exports are low, although for Turkmenistan the ratio is equal to $11 \%$ for multiple NTM categories.

Most of the NTMs imposed by Japan materialize in the form of SPS measures and TBTs. The latter are important for Belarus, Russia, and Turkmenistan. TBTs affect $39 \%$ of exports coming from Belarus, $38 \%$ of exports coming from Russia, and $50 \%$ of exports coming from Turkmenistan. SPS measures affect $50 \%$ of Turkmenistan's exports. Quantitative controls are important for Uzbekistan as $98 \%$ of the exports from this country are subjected to this type of NTM. Prices control measures only affect exports from Russia, although the magnitude of the coverage ratio is very low. But charges, taxes, and other para-tariff measures impact $44 \%$ of the exports from Russia. Coverage ratios measured with total exports to the world do not exceed $1 \%$.

Eurasia's exports to the EU are clearly affected by technical barriers to trade. Countries such as Azerbaijan, Kazakhstan, Russia, Tajikistan, Turkmenistan, and Belarus have more than $85 \%$ of their exports to the EU affected by this type of NTM. Between $50 \%$ and $60 \%$ of the exports from Armenia, Georgia, Moldova, Ukraine, and Uzbekistan are subjected to the same type of trade barrier. SPS measures are the second category in importance, affecting 21\% of Moldova's exports and $12 \%$ of Ukraine's exports. Pre-shipment inspections and quantitative controls have a minor effect. Since exports to the EU account for a large share of Eurasia's exports, the coverage ratios measured with total exports are larger than the ones calculated for the other destinations.

Table 11

Impact of NTMs on Eurasia's exports

Indonesia

\begin{tabular}{|c|c|c|c|c|c|c|c|c|c|c|c|c|c|c|c|c|c|c|c|c|c|c|c|c|c|c|c|}
\hline Armenia & \multicolumn{3}{|c|}{ Azerbaijan } & \multicolumn{3}{|c|}{ Belarus } & \multicolumn{3}{|c|}{ Georgia } & \multicolumn{3}{|c|}{ Kazakhstan } & \multicolumn{2}{|c|}{ Kyrgyzstan } & \multicolumn{2}{|c|}{ Moldova } & \multicolumn{3}{|c|}{ Russia } & \multicolumn{2}{|c|}{ Tajikistan } & \multicolumn{3}{|c|}{ Turkmenistan } & \multicolumn{2}{|c|}{ Ukraine } & Uzbekistan \\
\hline В $31 \% 0 \%$ & A & $0 \%$ & $0 \%$ & B 1 & $100 \%$ & $1 \%$ & B & $5 \%$ & $0 \%$ & A & $1 \%$ & $0 \%$ & A $31 \%$ & $0 \%$ & B $24 \%$ & $0 \%$ & A & $1 \%$ & $0 \%$ & B $100 \%$ & $0 \%$ & A & $86 \%$ & $0 \%$ & A $6 \%$ & $0 \%$ & A $27 \% 0 \%$ \\
\hline \multirow[t]{3}{*}{ Е $69 \% 0 \%$} & B & $0^{\circ}$ & $0 \%$ & $\mathrm{C}$ & $0 \%$ & $0 \%$ & & $47 \%$ & $0 \%$ & B & $49 \%$ & $0 \%$ & B $18 \%$ & $0 \%$ & C $37 \%$ & $0 \%$ & & $53 \%$ & $0 \%$ & & & B & $5 \%$ & $0 \%$ & B $51 \%$ & $1 \%$ & В $70 \% 0 \%$ \\
\hline & $\mathrm{C}$ & $0^{\circ}$ & & E & $0 \%$ & & & $47 \%$ & $0 \%$ & $\mathrm{C}$ & $0 \%$ & $0 \%$ & C $19 \%$ & $0 \%$ & Е $39 \%$ & $0 \%$ & $\mathrm{C}$ & $0 \%$ & & & & $\mathrm{C}$ & $5 \%$ & $0 \%$ & C $\quad 0 \%$ & & C $\quad 0 \% 0 \%$ \\
\hline & $\mathrm{N}$ & $0^{\circ}$ & $0 \%$ & & & & & & & $\mathrm{~N}$ & $0 \%$ & $0 \%$ & $\mathrm{~N} \quad 0 \%$ & $0 \%$ & & & $\mathrm{H} 4$ & $40 \%$ & $0 \%$ & & & & & & H $6 \%$ & $0 \%$ & \\
\hline
\end{tabular}

China

\begin{tabular}{|c|c|c|c|c|c|c|c|c|c|c|c|c|c|c|c|c|c|c|c|c|c|c|}
\hline Armenia & \multicolumn{2}{|c|}{ Azerbaijan } & \multicolumn{2}{|c|}{ Belarus } & \multicolumn{2}{|c|}{ Georgia } & \multicolumn{2}{|c|}{ Kazakhstan } & \multicolumn{2}{|c|}{ Kyrgyzstan } & \multicolumn{2}{|c|}{ Moldova } & \multicolumn{2}{|c|}{ Russia } & \multicolumn{2}{|c|}{ Tajikistan } & \multicolumn{2}{|c|}{ Turkmenistan } & \multicolumn{2}{|c|}{ Ukraine } & \multicolumn{2}{|c|}{ Uzbekistan } \\
\hline II & I & II & I & II & I & II & I & II & I & II & I & II & I & II & I & II & I & II & I & II & I & II \\
\hline
\end{tabular}

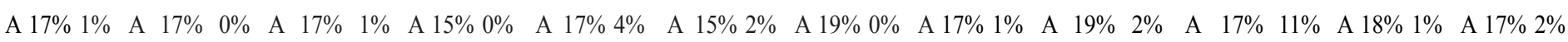

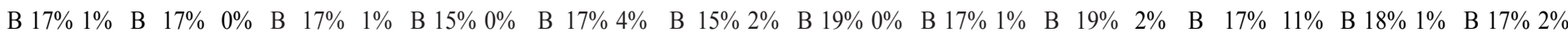

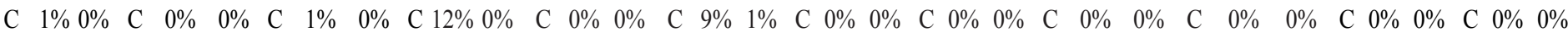

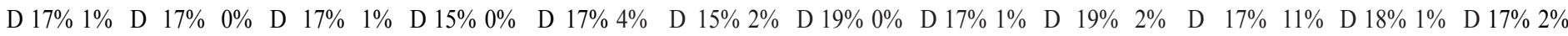

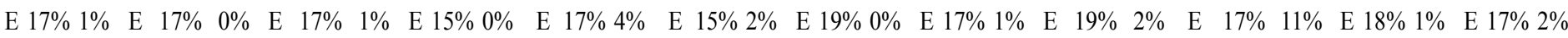

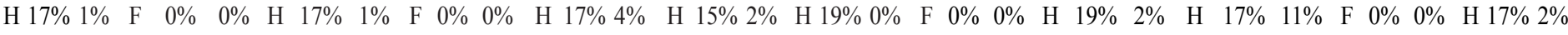

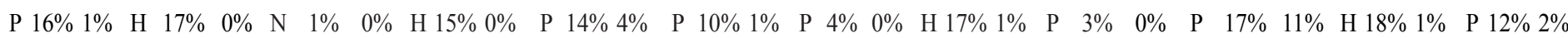
$\begin{array}{lllllllllll}\mathrm{P} & 13 \% & 0 \% & \mathrm{P} & 14 \% & 1 \% & \mathrm{P} & 12 \% & 0 \%\end{array}$ P $7 \% \quad 0 \%$ 


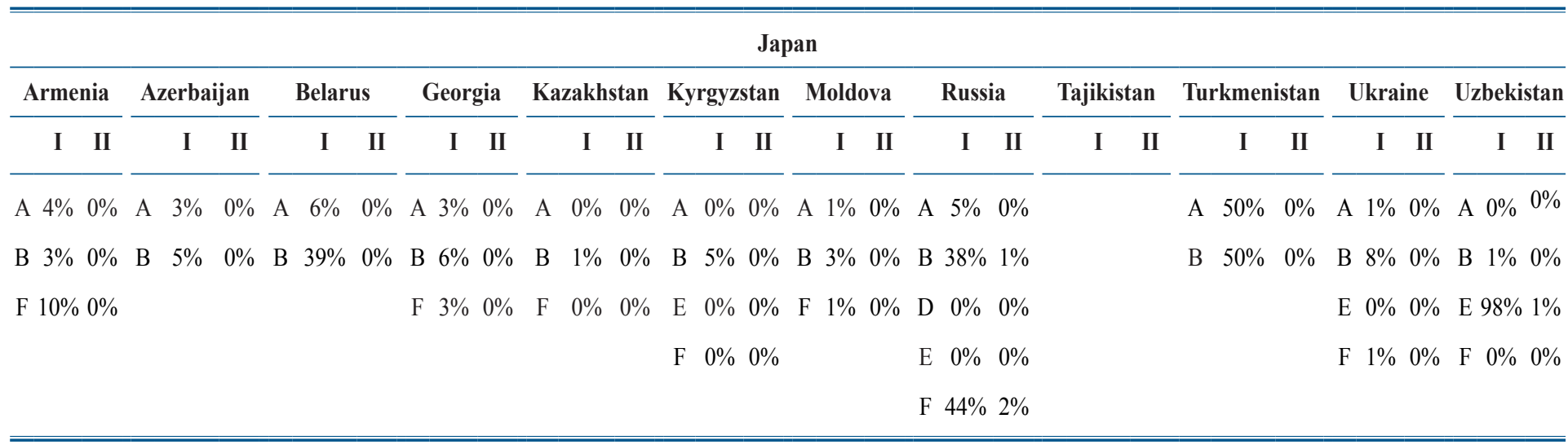

EU

\begin{tabular}{|c|c|c|c|c|c|c|c|c|c|c|c|}
\hline Armenia & Azerbaijan & Belarus & Georgia & Kazakhstan & Kyrgyzstan & Moldova & Russia & Tajikistan & Turkmenistan & Ukraine & Uzbekistan \\
\hline
\end{tabular}

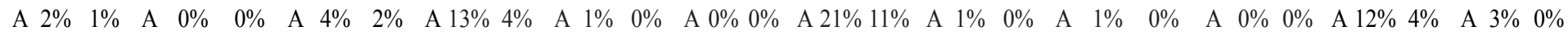

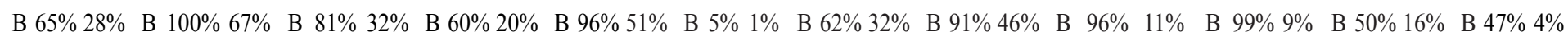

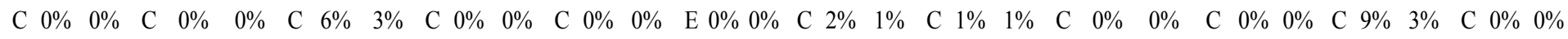

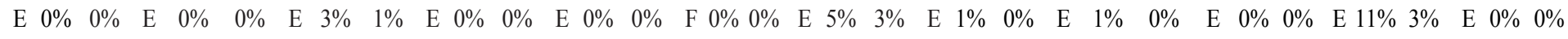
Source: Authors' calculations using NTM and tariff data from UNCTAD and trade data from UN Comtrade accessed through WITS (2012).

\section{ANTIDUMPING, SAFEGUARDS, AND COUNTERVAILING DUTY POLICIES}

Antidumping, safeguards, and countervailing duty policies are other types of trade policy barriers. ${ }^{8}$ After the global financial crisis of $2008+$, many developed and developing countries increased the use of TTBs to protect domestic industries, thereby constraining trade. Between 2007 and 2009, seven major emerging economy G20 members collectively increased by roughly $40 \%$ the share of non-oil import product lines affected by this type of restriction (Bown, 2012). Table 12 summarizes newly constructed indicators of TTBs, which have been assembled by Bown (2012). Column 2 of Table 12 reports the share of import product lines, at the 6-digit Harmonized System level, over which the policy-imposing economy had at least one import-restricting TTB in effect in 2011. This measure captures the stock of products covered by the accumulation of TTBs over time and were in effect in 2011. Columns 4 through 8 present other indicators constructed with trade data.

\footnotetext{
8 Anti-dumping duties are allowed under GATT's Article 6 to be imposed on goods that are deemed to be dumped and causing injury to producers of competing products in the importing country. Safeguard measures are actions taken to protect a specific industry from an unexpected build-up of imports - generally governed by Article 19 of GATT. Countervailing measures are actions taken by the importing country, usually in the form of increased duties, to offset subsidies given to producers or exporters in the exporting country.
} 
Table 12

TTB Policy-Imposing Economies and Affected Imports in 2011

\begin{tabular}{|c|c|c|c|c|c|c|c|}
\hline \multirow[b]{2}{*}{ Country } & \multicolumn{2}{|c|}{$\begin{array}{l}\text { Product line share } \\
\text { of imports }\end{array}$} & \multicolumn{5}{|c|}{2011 trade-weighted share of imports ${ }^{a}$} \\
\hline & $\begin{array}{l}\text { All TTBs } \\
\text { in } 2011^{b}\end{array}$ & $\begin{array}{l}\text { All TTBs } \\
\text { in } 2001^{b}\end{array}$ & All TTBs ${ }^{C, b}$ & $\mathbf{A D}^{\mathbf{d}}$ only $\mathbf{y}^{\mathbf{b}}$ & From China & $\begin{array}{c}\text { From other } \\
\text { emerging } \\
\text { economies }\end{array}$ & $\begin{array}{l}\text { From high- } \\
\text { income } \\
\text { economies }\end{array}$ \\
\hline China & 1.4 & 0.3 & 3.2 & 3.2 & . & 1.1 & 3.9 \\
\hline Indonesia & 1.8 & 0.9 & 1.2 & 0.8 & 2.4 & 1.5 & 0.8 \\
\hline Malaysia & $<0.1$ & $<0.1$ & 0.2 & 0.2 & $<0.1$ & 0.4 & 0.1 \\
\hline European & 3.1 & 2.3 & 1.8 & 1.7 & 4.2 & 1.2 & 0.8 \\
\hline Korea & 0.6 & 0.6 & 0.4 & 0.4 & 0.6 & 0.9 & 0.1 \\
\hline Japan & $<0.1$ & 0.1 & $<0.1$ & $<0.1$ & $<0.1$ & $<0.1$ & $<0.1$ \\
\hline
\end{tabular}

The EU is the trading partner that subjects the highest percentage of import lines to at least one TTB, 3.1\%. Indonesia and China follow in the list, with $1.8 \%$ and $1.4 \%$ of the products affected by antidumping, safeguards and/or countervailing measures. Korea, Malaysia, and Japan are the least protectionist countries. Less than $0.1 \%$ of the product lines have at least one TTB. If we compare the share of goods affected by at least one TTB between 2001 and 2011, we observe that half of the trading partners increased their coverage during the period analyzed. The increment varies between 0.8 and 1.1 percentage points for the EU and China, respectively.

China is the trading partner with the largest proportion of imports affected by a TTB, $3.2 \%$, followed by the EU, 1.8\%. Antidumping measures are very important in the EU as more than $90 \%$ of the share of imports affected by at least one TTB is subjected to an antidumping policy. The percentage of imports coming from an emerging economy (excluding China) that are affected by a TTB varies between $0.1 \%$ for Japan and $1.5 \%$ for Indonesia. The percentage varies between $0.1 \%$ and $3.9 \%$ if the imports come from a high-income economy.

Russia and Ukraine lead, together with Vietnam, the list of emerging economies whose exports are subjected to a TTB. Table 13 presents the percentage of export values affected by foreign-imposed TTBs. In the case of Russia, $5.8 \%$ of exports oriented to the countries of the sample received a TTB in 2011. This includes 7.9\% of exports to G20 high-income countries, $1.8 \%$ of exports to G20 emerging countries, and $0.7 \%$ of exports to other economies. In the case of Ukraine, 5.7\% of overall exports were affected by a TTB. As was observed for Russia, exports to G20 high-income countries were the most affected (7.9\%), followed by those to G20 emerging economies $(1.8 \%)$, and those to other countries $(0.7 \%)$. Kazakhstan presents a lower percentage of exports subjected to foreign-imposed TTBs (1.7\%), but it registers a higher fraction of exports to non-G20 countries affected by this type of policy barrier, $36.9 \%$. Almost all exports to the G20 emerging economies are not subjected to TTBs.

For Kazakhstan, Ukraine, and Russia, a lower percentage of overall exports were affected by TTBs in 2011 than in 2001. The difference is significant in Ukraine: 7.1 percentage points for total exports and 17 percentage points for exports to G20 emerging countries. The case of Kazakhstan is different because a larger share of exports to non-G20 countries is exposed to TTBs. In 2001, only $11.4 \%$ of the exports to those destinations were subjected to at least one TTB, while that percentage jumped to $36.9 \%$ by 2011 . 
Table 13

Economies with Significant Exports Subjected to Foreign-Imposed TTBs: 2001 vs. 2011

\begin{tabular}{|c|c|c|c|c|c|c|c|c|}
\hline \multirow{2}{*}{ Country } & \multicolumn{4}{|c|}{$\begin{array}{c}\text { TTB-affected share of exports } \\
\text { in } 2011 \text { to... }\end{array}$} & \multicolumn{4}{|c|}{$\begin{array}{c}\text { TTB-affected share of exports } \\
\text { in } 2001 \text { to... }\end{array}$} \\
\hline & $\mathbf{A l l}^{\mathrm{b}}$ & $\begin{array}{c}\text { G20 } \\
\text { high-income }\end{array}$ & $\begin{array}{c}\text { G20 } \\
\text { emerging }\end{array}$ & Other ${ }^{c}$ & All ${ }^{b}$ & $\begin{array}{c}\text { G20 } \\
\text { high-income }\end{array}$ & $\begin{array}{c}\text { G20 } \\
\text { emerging }\end{array}$ & Other \\
\hline Vietnam & 6.2 & 8.1 & 1.3 & $<0.1$ & 0.2 & 0.2 & 0.4 & $<0.1$ \\
\hline Russia & 5.8 & 6.3 & 5.5 & 1.4 & 7.0 & 7.6 & 6.2 & 1.6 \\
\hline Ukraine & 5.7 & 7.9 & 1.8 & 0.7 & 12.8 & 12.2 & 18.8 & 1.3 \\
\hline China & 4.9 & 4.7 & 10.8 & 1 & 3.2 & 3.4 & 4.2 & 0.2 \\
\hline India & 2.5 & 2.8 & 2.5 & 0.5 & 4.4 & 5.1 & 1.8 & $<0.1$ \\
\hline Thailand & 2.5 & 2.7 & 3 & 0.5 & 3.2 & 3.9 & 1.4 & 0.1 \\
\hline Pakistan & 2.4 & 1.6 & 5.3 & 1.3 & 7.8 & 9.1 & 0.4 & $<0.1$ \\
\hline Mexico & 2.1 & 2.3 & 0.5 & $<0.1$ & 1.1 & 1.1 & 2.1 & 0.4 \\
\hline Kazakhstan & 1.7 & 2.8 & 0.2 & 36.9 & 4.1 & 5 & 2.4 & 11.4 \\
\hline Indonesia & 1.7 & 1.2 & 3.4 & 1.1 & 3.7 & 4.6 & 1.5 & 0.4 \\
\hline Brazil & 1.1 & 1.5 & 0.7 & $<0.1$ & 2.1 & 1.9 & 3.4 & 0.4 \\
\hline Malaysia & 0.9 & 0.9 & 1.2 & 0.3 & 1.2 & 1.5 & 0.2 & $<0.1$ \\
\hline South Africa & 0.4 & 0.3 & 0.4 & 1.0 & 1.0 & 1.1 & 0.8 & $<0.1$ \\
\hline Argentina & 0.4 & 0.4 & 0.2 & 0.8 & 3.5 & 2.2 & 2.7 & 10.4 \\
\hline Turkey & 0.1 & 0.1 & $<0.1$ & 0.3 & 1.1 & 1 & 2.4 & 0.8 \\
\hline Other emerging economies & 0.2 & 0.2 & 0.4 & 0.1 & 0.7 & 0.6 & 1.9 & 0.3 \\
\hline
\end{tabular}

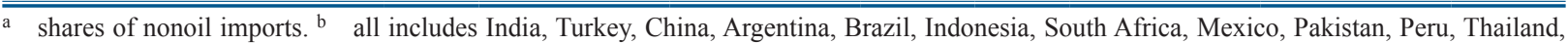
Colombia, Malaysia, Philippines, Chile, United States, European Union, Canada, Australia, South Korea, Japan, New Zealand, Israel, Taiwan. c other policy-imposing economies include Pakistan, Peru, Thailand, Colombia, Malaysia, Philippines, Chile, New Zealand, Israel, and Taiwan, China.

Source: Bown (2012).

Data on antidumping investigations show that EAP countries have not opened antidumping investigations against Eurasian economies. But this is not the case with the EU, as most of the countries of the region have been exposed to antidumping investigations. Russia is the country with the highest number of investigations opened by the EU, 32, followed by Ukraine, 21, and Belarus, 9. In the case of Russia, $84.3 \%$ of the cases were associated to a final affirmative dumping decision, while for Ukraine it was $76.2 \%$. For the rest of the economies, the rate of affirmative cases varied between $0 \%$ for Uzbekistan, Turkmenistan, and Georgia, and 100\% for Moldova and Kyrgyzstan. Safeguards in the EU are related to products such as steel, mandarins, salmon, strawberries, and wireless wide area networking (World Bank's Global Antidumping Database, 2012). Indonesia applies safeguards to a larger set of products, for example, lighters, glass, aluminum foil food containers, wire of iron, cotton yarn, woven fabrics of cotton, tarpaulins, articles of iron or steel wire, conveyor belts, articles of finished casing and tubing, polypropylene in granule form, and mackerel. The rest of Eurasia's trading partners considered in this note do not apply any safeguards against Eurasia. Countervailing measures against the region are absent from China, Japan, and the EU. 
Table 14

Antidumping Investigations

\begin{tabular}{lcccccc}
\hline \multirow{2}{*}{$\begin{array}{c}\text { Country } \\
\text { under investigation }\end{array}$} & \multicolumn{6}{c}{ Antidumping investigations ${ }^{\mathbf{a}}$} \\
\cline { 2 - 7 } Armenia & China & Indonesia & Japan & Korea & Malaysia & EU \\
Azerbaijan & 0 & 0 & 0 & 0 & 0 & 1 \\
Belarus & 0 & 0 & 0 & 0 & 0 & 0 \\
Georgia & 0 & 0 & 0 & 0 & 0 & 9 \\
Kazakhstan & 0 & 0 & 0 & 0 & 0 & 2 \\
Kyrgyz & 0 & 0 & 0 & 1 & 0 & 6 \\
Moldova & 0 & 0 & 0 & 0 & 0 & 1 \\
Russia & 0 & 0 & 0 & 0 & 0 & 1 \\
Tajikistan & 0 & 3 & 0 & 5 & 0 & 32 \\
Turkmenistan & 0 & 0 & 0 & 0 & 0 & 0 \\
Ukraine & 0 & 0 & 0 & 0 & 0 & 1 \\
Uzbekistan & 0 & 2 & 0 & 0 & 0 & 21 \\
\hline \hline
\end{tabular}

data available to 2011.

Source: World Bank's Global Antidumping Database (2012).

\section{PREFERENTIAL TRADE AGREEMENTS}

Following the dissolution of the Soviet Union in 1991, the economies of Eurasia concluded a plethora of trade agreements with countries throughout the world but primarily among themselves in an effort to maintain the economic integration of the region. The result was a 'spaghetti bowl' of trade agreements. In fact, 31 out of the 39 bilateral free trade agreements (FTAs) that Eurasian economies have concluded are between two countries in the region, and 26 of these entered into force in the 1990s. This is in addition to four plurilateral regional trade agreements (RTAs) concluded solely between Eurasian countries with another in early announcement. Figure 3 provides a pictorial representation of the 'spaghetti bowl' effect; each oval represents a distinct RTA, and the countries contained within each oval are those countries party to the RTA. The appendix provides a more detailed list of regional and bilateral trade agreements signed by Eurasian economies. In addition, other regional organizations have been used as platforms to build regional integration and trade facilitation initiatives. ${ }^{9}$ Bilateral and plurilateral RTAs also exist between Eurasian countries and parties outside the region, although Moldova and Ukraine have been the most successful in negotiating these. Many are in early announcement, suggesting Eurasian countries are just beginning to shift their focus for preferential trade initiatives to outside the region.

Trade agreements can potentially result in trade creation through tariff reductions, trade diversion from third parties through increased preference margins, and export market diversification within and outside the region. In the case of Eurasia, most of the RTAs are not fully implemented or enforced, have narrow coverage, overlapping membership, and complex origin

\footnotetext{
For example, Armenia, Azerbaijan, Georgia, Moldova, Russia, and Ukraine are members of the Black Sea Economic Cooperation Organization, established in 1992, together with Albania, Bulgaria, Greece, Romania, and Turkey. Other examples include: Collective Security Treaty Organization (1992), Union State of Russia and Belarus (1997), CAREC (1997), Shanghai Cooperative Organization (2001), and The Central Asian Cooperation Organization (2002-5).
} 
requirements. Trade policies can change frequently and are unpredictable for non-WTO member countries in Eurasia. This creates barriers to trade as it increases the scope for corruption and creates uncertainty and distrust among the members. In addition, the list of products exempted from the free trade regimes is extensive. Where RTAs have been implemented, various non-tariff barriers (NTBs) often hamper trade among the signatory countries. These include licensing, export bans and implicit tariffs in the form of various taxes on imports that are not levied on domestically produced goods or have discriminatory rates. Although average tariffs for most countries remain low, they remain relatively unchanged over the past decade. Border management remains inefficient, particularly for small traders (Gillson and Reyes, 2011; World Bank, 2011).

The major plurilateral RTAs concluded by Eurasian countries include the following (see Asian Development Bank (2006) for a more complete summary).

- The Commonwealth of Independent States (CIS) was established in 1991 to strengthen traditional economic links by coordinating economic policies and institutional arrangements. In 1993, the CIS countries committed themselves to the gradual creation of an economic union - a common economic space with free movement of goods, services, capital, and labor. It was to start with a plurilateral FTA and culminate in an economic union with the same monetary unit. In 1994, CIS member states signed the Agreement on the Establishment of a Free Trade Area so as to implement the provisions of the treaty, but were not able to agree on a common list of exemptions from the free trade regime. In 1999, they amended the agreement, whereby the list of exemptions could be agreed upon on a bilateral basis, but not all countries were able to achieve this. Thus, the agreement has not been fully implemented. There is now another proposed FTA in early announcement between eight members of the CIS.

- $\quad$ The Eurasian Economic Union or Community (EEU or EAEC) started in 1995 when Russia, Kazakhstan, and Belarus agreed to establish a customs union. Kyrgyzstan joined in 1996 and Tajikistan in 1998, and were to establish a common external tariff schedule by 2006. Kazakhstan, Belarus, and Russian Federation, however, were able to achieve this in 2010, and is considered the most successful attempt at regional integration. Although, it has been documented that Kazakhstan's external tariffs increased after joining the customs union with Belarus and Russia.

- In 1996, Georgia, Ukraine, Azerbaijan and Moldova set up the Organization for Democracy and Economic Development, a mutual support group with the main goal of setting up transit routes and military assistance, and Uzbekistan joined in 1999. In 2000 these GUUAM countries announced they would establish an FTA.

- Despite the EAEC, in 2004 the Common Economic Zone or Single Economic Space (CEZ or SES) was set up between Belarus, Kazakhstan, Russian Federation, and Ukraine. The agreement was to establish a free trade zone with the ultimate goal of creating an economic union.

- In 1992, six Eurasian economies joined the Economic Cooperation Organization (ECO) and in 2003 signed an ECO Trade Agreement with Afghanistan, Iran, Pakistan, and Turkey. The agreement envisioned a reduction of tariffs to a maximum of $15 \%$ for at least $80 \%$ of the traded goods within eight years after its entry into force, which occurred in 2008 after five countries signed the agreement.

- $\quad$ The Central European FTA (CEFTA) was originally signed by Poland, Hungary, Czech Republic and Slovakia in 1992 and put into force in 1994, to later include Slovenia, Romania, Bulgaria, Croatia and Macedonia. After many of its original member had left when joining the EU, it was extended in 2006 and put into force in 2007 to include Albania, Bosnia and Herzegovina, Moldova, Montenegro, Serbia and Kosovo, with the aim of establishing a free trade zone in the region by 2010. 
Eurasian countries' major trading partners of the EU and EAP have successfully negotiated trade agreements with many parts of the world. Such agreements have the potential to divert trade from Eurasian economies to third parties with preferential access to these markets. The EU, itself a customs union, has 33 RTAs in force and notified to the WTO with three additional in early announcement. ${ }^{10}$ To date, however, Ukraine is the only Eurasian country to have negotiated an FTA with the EU, which is in early announcement. Iceland, Liechtenstein, Norway, and Switzerland have an FTA with Ukraine and another with Belarus, Russia, and Kazakhstan in early announcement. EAP countries have also been successful at creating trade initiatives both within and outside the region through regional institutions such as ASEAN and APEC. Many FTAs have been forged between these countries and, for example, Australia, India, Peru, Mexico, New Zealand, and India. Singapore and Malaysia have been particularly successful at negotiating agreements outside of the region. However, no agreements exist between EAP and Eurasian countries with the exception of Ukraine and Singapore in early announcement.

Despite two decades of Eurasian countries implementing significant trade policy initiatives, few or no RTAs exist between these countries and the EU or those in EAP. We reconcile this in part by the strong preference for regional integration following the dissolution of the Soviet Union. Integration initiatives have been mainly directed at re-establishing the economic links that existed before the fall of the communist bloc. Most of these countries are economically small and some are landlocked. In this context, deeper regional integration is not only important to secure market access in neighboring markets, effectively increasing the market size for any country in the region and allowing the realization of scale economies, but also to encourage foreign investments in vertical specialization and regional value chains for sales to global markets (Gillson and Reyes, 2011). Only recently have Eurasian countries shifted focus to outside the region.

The inability to effectively implement RTAs within the Eurasian region and the limited scope of RTAs outside of Eurasia suggest that multilateralism through WTO accession would have considerable benefits. Multilateral initiatives could erode such preference margins. Half of the countries in Eurasia have successfully acceded to the WTO; Kyrgyzstan was the first in 1998 and Russia the latest in 2012, as well as Armenia (2003), Georgia (2000), Moldova (2001), and Ukraine (2008). Five other countries currently have ongoing accessions, with applications received over ten years ago (Azerbaijan 1997, Belarus 1993, Kazakhstan 1996, Tajikistan 2001, and Uzbekistan 1994). Turkmenistan is the only country in the region that has not acceded or begun accession to the WTO. All members of the EU are WTO members as well as 18 EAP countries. ${ }^{11}$

\footnotetext{
10 Countries for which the EU has concluded trade agreements include: Albania, Algeria, Andorra, Bosnia and Herzegovina, Cameroon, CARIFORM states (Antigua and Barbuda, Bahamas, Barbados, Belize, Dominica, Dominican Republic, Grenada, Guyana, Jamaica, St. Kitts and Nevis, St. Lucia, St. Vincent and the Grenadines, Suriname, Trinidad and Tobago), Chile, Cote d'Ivoire, Croatia, Eastern and Southern African States (Madagascar, Mauritius, Seychelles, Zimbabwe), Egypt, Faroe Islands, Macedonia, FYR, Iceland, Israel, Jordan, Korea, Lebanon, Mexico, Montenegro, Morocco, Norway, Overseas Countries and Territories (British Indian Ocean Territory; Cayman Islands; Falkland Islands (Islas Malvinas); French Polynesia; French Southern Territories; Greenland; Mayotte; Montserrat; Netherlands Antilles; New Caledonia; Pitcairn; Saint Helena; Saint Pierre and Miquelon; South Georgia and the South Sandwich Islands; Turks and Caicos Islands; Virgin Islands, British; Wallis and Futuna Islands), Palestinian Authority, Papua New Guinea and Fiji, San Marino, Serbia, South Africa, Switzerland the Lichtenstein, Syria, Tunisia, Turkey, European Economic Area (Iceland, Liechtenstein, Norway), Canada, India, Ukraine.

11 Including: American Samoa, Brunei Darussalam, Cambodia, China, Korea, Fiji, Indonesia, Japan, Lao PDR, Malaysia, Mongolia, Myanmar, Papua New Guinea, Philippines, Thailand, Timor-Leste, Vanuatu, and Vietnam.
} 
Figure 3

Plurilateral Regional Trade Agreements of Eurasian Countries

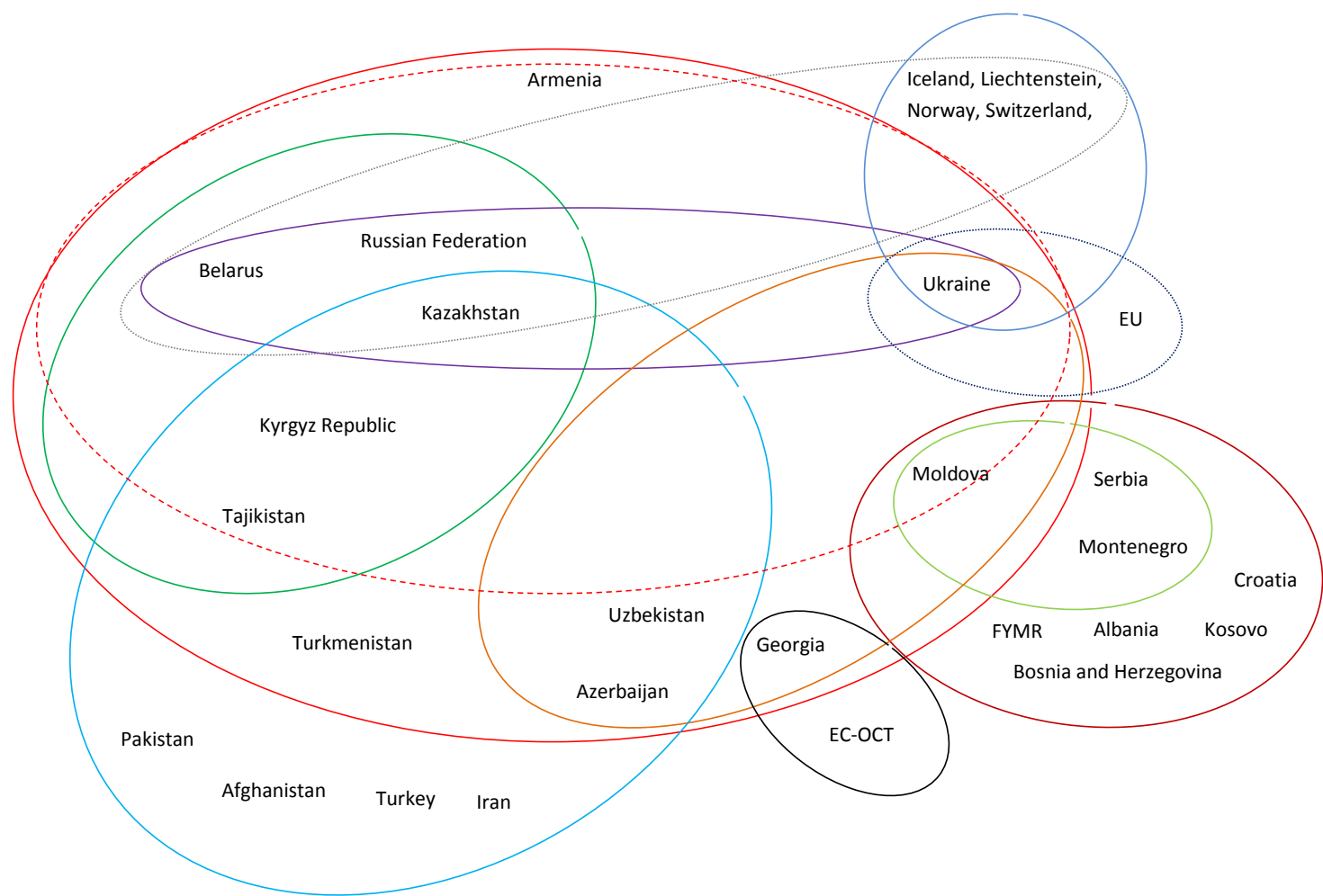

Figure 3 presents a pictorial representation of the regional trade agreements that Eurasian countries have signed. Each oval represents a distinct regional trade agreement, and the countries contained within each oval are those countries party to the agreement.

Source: Authors' elaboration using data from WTO and Global Preferential Trade Agreements Library accessed through WITS (2012)

\section{TRADE POLICY BARRIERS IN SERVICES}

We start the analysis of trade policy barriers in services with the examination of trade barriers in the Eurasian region, as domestic policy constraints may dampen competition and create antiexport bias. To conduct the analysis, we employ a new dataset constructed by Borchert et al. (2012a; 2012b), which provides trade restrictiveness indexes and detailed information on policy restrictions in the services arena. Restrictions to services trade considered in the dataset include: i) cross-border supply of services (mode 1), ii) supply of services through commercial presence (mode 3), and iii) temporary presence of natural persons (mode 4). The perspective is one of a foreign service provider that wishes to provide services to consumers in a foreign country, and therefore it considers policy measures that affect both domestic and foreign service provides as well as measures that discriminate against foreign service providers.

The database covers 103 countries across all regions and income groups of the world. For each country, five major service sectors are covered that encompass a total of 19 subsectors: i) financial: retail banking (lending and deposit acceptance) and insurance (automobile, life, and reinsurance); ii) telecommunications: fixed-line and mobile; iii) retail distribution; iv) transportation: air passenger (international and domestic), maritime shipping, maritime auxiliary, road trucking, and railway freight; and v) professional: accounting, auditing, and legal services (advice on foreign/international law, advice on domestic law, and court representation). Each subsector in turn covers the relevant modes of supplying the respective services, yielding overall 34 subsectormode combinations: mode 1: financial, transportation, and professional; mode 3: all subsectors; and mode 4: professional. 
The Services Trade Restrictions Index (STRI) takes a value between 0 and 100, with higher values indicating more restrictive regimes. Policy regimes are divided into five broad categories: i) completely open, i.e., no restrictions at all (0); ii) completely closed, i.e., no entry allowed at all (100); iii) virtually open but with minor restrictions (25); iv) virtually closed but with very limited opportunities to enter and operate (75); and v) a final residual "middle" category of regimes that allow entry and operations but impose restrictions that are neither trivial nor stringent (50).

The STRIs for Eurasia show that the region maintains virtually open regimes with minor restrictions (see Table 17 and Appendix for more details). The financial and telecommunication sectors are the ones with the highest barriers to trade. The most closed economy is Belarus, with an overall index of 35.1, followed by Ukraine (27.2), Russia (25.7), and Uzbekistan (23.4). Belarus's restrictions in telecommunications (mode 3) are associated to virtually closed regimes in fixed-line telecommunications. Beltelcom is a state-owned monopoly provider of services. If a foreign investor wishes to acquire a share of the incumbent, a resolution by the President is required. Constraints in telecommunications are also important in Russia and Uzbekistan. In the first case, entrance into fixed-line telecommunications must be done through a subsidiary. The radio frequency spectrum may be limited, but licenses are allocated first come, first served or by auction. In the second case, a limit on licenses applies. The number of licenses and the method of allocation are determined by the Cabinet of Ministers.

Table 15

Services Trade Restrictions Index in Eurasian Countries

\begin{tabular}{|c|c|c|c|c|c|c|}
\hline Country & Overall & Financial & Telecomm. & Retail & Transportation & Professional \\
\hline Belarus & 35.1 & 53.8 & 62.5 & 0 & 36.8 & 40 \\
\hline Ukraine & 27.2 & 24.4 & 25 & 25 & 26.7 & 35 \\
\hline $\begin{array}{l}\text { Russian } \\
\text { Federation }\end{array}$ & 25.7 & 46.7 & 50 & 0 & 14.2 & 32 \\
\hline Uzbekistan & 23.4 & 24.6 & 50 & 0 & 32.0 & 31.5 \\
\hline Kazakhstan & 17.0 & 22.1 & 25 & 0 & 16.4 & 28 \\
\hline Kyrgyzstan & 15.2 & 8.4 & 0 & 0 & 45.7 & 28 \\
\hline Georgia & 11.5 & 9.0 & 0 & 0 & 8.8 & 37 \\
\hline Armenia & 11.4 & 2.6 & 0 & 0 & 25.0 & 32 \\
\hline
\end{tabular}

Source: World Bank's Services Trade Restrictions Database (2012).

Restrictions in the financial sector are relevant in Belarus and Russia. In the case of Belarus, a license for providing some banking services can be obtained two years after registration of the bank. There is a limit on licenses, due to a $50 \%$ threshold on foreign investment in the banking sector. If this limit is reached, foreign investment in banking would not be possible. In the case of automobile and life insurance, entry through a branch is not allowed. For entry through a subsidiary and acquisition, the foreign ownership limit is $49 \%$. For a single foreign investor, the foreign ownership limit is $35 \%$. In the case of Russia, entry in the banking system is possible through a subsidiary and/or representative office. There is no limit on foreign ownership. However, the limit on overall foreign investment in the banking sector is $12 \%$ of the overall assets of the bank. Licenses are subject to authorization of the Central Bank on a nondiscriminatory basis. At least $50 \%$ of the Board of Directors and $75 \%$ of the employees of the company should be Russian.

Trade policy barriers in the transportation sector are relatively important in Kyrgyzstan and Belarus, with STRI indexes of 45.7 and 36.8, respectively. In both cases, constrains are mainly 
associated to rail freight as the market is closed under a state monopoly. Trade policy barriers for countries with relatively low restrictions have been concentrated in professional services. In Ukraine, constraints appear in mode 4. For auditing services, there is an education requirement; foreign degrees are recognized if deemed acceptable to the Ukrainian authorities under the international treaties to which Ukraine is party to. Three years of work experience in Ukraine is required. Applicants must also pass an examination. Legal services (mode 4) in Georgia and Russia are completely closed as there is a nationality requirement. In Armenia, accounting and auditing services under mode 1 are not allowed. Barriers in Belarus are mainly applied to accounting and auditing services under mode 1 and 4 . Mode 1 is allowed, but the person who signs off on financial statements must be locally licensed. Firms may set up a representative office (mode 3), but not a branch. No license is required, but registration is necessary to set up a legal entity.

Eurasia's trading partners considered in this note have intermediate levels of restrictiveness, with Indonesia registering the highest overall STRI (Table 18). Restrictions are significant in categories such as professional services, transportation, and retail. In the case of professional services, barriers appear in the supply of services through commercial presence (mode 3), which is not allowed. In the case of transportation, restrictions are high $(\mathrm{STRI}=100)$ in rail and road freights, which are also closed under mode 3. In retail, the country presents middle levels of openness. There is no limit on foreign ownership under mode 3. Entry of foreign suppliers is subject to the following conditions: 1) be a large scale retailer, 2) located in the regency/city, with a minimum land area of $2,000 \mathrm{~m}^{2}$, and 3) cooperate with local small-scale businesses. Trade policy barriers in telecommunications and financial services are low. In the case of telecommunications, applicants must form a joint venture. The limit on foreign ownership is $95 \%$, which may be reduced to $35 \%$. The number of licenses is not fixed, but allocated at the discretion of the regulator. The highest level of protection in the financial sector is associated to insurance services under mode 3 (STRI=41.67). Entry is allowed only through subsidiary and acquisition. If the local firm is private, the foreign ownership limit is $80 \%$. Subsidiaries must form joint ventures with local partners and meet minimum capital requirements. One member of the Board of Directors must be Indonesian.

Table 16

Services Trade Restrictions Indexes of East Asia and the Pacific and the European Union

\begin{tabular}{lcccccc}
\hline \hline \multicolumn{1}{c}{ Country } & Overall & Financial & Telecomm. & Retail & Transportation & Professional \\
\hline Indonesia & 50.0 & 23.4 & 25 & 50 & 66.4 & 76 \\
Malaysia & 46.1 & 44.6 & 25 & 25 & 55.4 & 73 \\
China & 36.6 & 34.8 & 50 & 25 & 19.3 & 66 \\
Europe $^{\mathrm{a}}$ & 26.1 & 4.2 & 0 & 25 & 37.1 & 54 \\
Japan & 23.4 & 1.9 & 25 & 25 & 15.6 & 56 \\
Korea Rep. & 23.0 & 2.3 & 50 & 0 & 20.8 & 66 \\
\hline \hline
\end{tabular}

a Europe include 20 countries for which data is available.

Source: World Bank's Services Trade Restrictions Database (2012)

Malaysia is the second most restrictive destination considered according to trade policy barriers in services. As in the case of Indonesia, constrains are mainly observed in the professional and transportation sectors. Contrary to the Indonesian case, trade policy barriers in the financial sector are not minor. In the case of professional services, auditing activities under modes 1 and 4 are not allowed. Ownership by foreign nationals (accounting and auditing services) is limited 
to $30 \%$. Ownership by non-locally-licensed professionals is not permitted. There must be at least one Malaysian partner in the firm. Malaysia is completely closed in rail freight services as rail transport is wholly owned by the state. However, there are no restrictions on legal form of entry for international airlines to operate international services into Malaysia. In maritime shipping, entry is allowed only through a representative office, regional office, or locally incorporated joint venture subsidiary, with Malaysian individuals or Malaysian-controlled corporations or both. The limit on aggregate foreign ownership in the joint venture and state-owned entity (merger and acquisition) is 30\%. Regarding road freight services, several types of licenses are available. License $\mathrm{A}$ is given to companies with a foreign ownership limit of $49 \%$ and equity of $30 \%$. The license is also given to companies with full foreign ownership if services rendered, including renting and hiring for activity, technology, vehicles, and expertise, are not available in Malaysia. License $\mathrm{C}$ is given to companies with full foreign ownership in the manufacturing sector to transport their own freight. Insurance services under mode 1 are the main source of restrictions in the financial sector, which is allowed under demonstrations of domestic unavailability.

China's restrictions are concentrated in the professional, telecommunications, and financial sectors. In the professional sector, constraints are related to legal services under modes 3 and 4, as legal advice on domestic law and legal representation in court are not allowed. Legal advice on foreign law can be conducted only by representative offices (branches), but a separate legal entity is not allowed. All forms of telecommunication services have the same score, 50. The limit on foreign ownership is $49 \%$. There is a minimum registered capital requirement of RMB 1 billion for foreign-invested telecommunications enterprises providing basic telecommunications services nationally, and RMB 100 million for such enterprises operating at the provincial level. Constraints on financial services are mainly related to cross-border supply of services (mode 1). Life and automobile insurance and acceptance of deposits by banks are not allowed. There is no limit on foreign ownership for retailers, except in the following case: the limit on foreign ownership is $49 \%$ if (1) the retailer sells books, newspapers, magazines, pharmaceutical products, mulching films, chemical fertilizers, processed oil, cotton, grain, vegetable oil, sugar, or pesticides, and (2) if the same retailer has set up 30 or more stores that sell goods of different types and brands from multiple suppliers. The sale of tobacco is not allowed. If a chain enterprise engages in the nationwide distribution of books, newspapers, and magazines, it shall have registered capital of no less than RMB 10 million and it shall have 10 or more regular chain stores; if such an enterprise operates on a sub-national level the minimum registered capital shall not be less than RMB 3 million. The license term is 30 years (40 if established in central/western regions); after expiry the firm must re-apply. Restrictions on transport services are mainly due to constraints for international air passenger services. The limit on foreign ownership is $49 \%$. The operating term is limited to 30 years.

The EU's policy barriers in services are focused on the professional, transportation, and retail sectors. Legal services under mode 4 are the ones with the highest restrictions (STRI=66.67). EU/EEA nationality or admission to the Bar in an EU member state is required in about half of all member states. Only in a few instances is entry allowed with minor restrictions. Entry requirements (education, work experience, training, license recognition, quotas, etc.) are typically reduced or simplified for nationals from EU/EEA countries. In the transport sector, road freight services under mode 3 is the category with the highest level of protection (STRI=75), as the foreign provision of the service is not allowed in Belgium, Czech Republic, Denmark, France, Germany, Greece, Hungary, Ireland, Netherlands, Portugal, Spain, and the United Kingdom. Retail services are allowed in all member states. With the exception of Finland, countries have no systematic difference in policies towards intra-EU and extra-EU suppliers.

Japan is one of the least protectionist trading partners of Eurasia in the EU and the EAP regions. The highest constraints are observed in professional services. Legal advice under mode 1 is not allowed. Accounting and auditing services under mode 4 face some constraints. Foreign 
licensed professionals are eligible to practice by meeting certain conditions. They must be qualified as 'Koninkaikeishi' under Japanese law, which involves the following requirements: 1) attending the three-year professional accountancy program only available in Japan, 2) two years of training is required and, 3) passing a local examination is necessary. The exam is given only in Japanese. Service suppliers must stay in Japan for at least 180 days a year. Telecommunications services (fixed-line and mobile) are relatively open. There is no limit on foreign ownership in other telecommunications suppliers. Retail services are also open. Restrictions may apply to the following products: petroleum, petroleum products, rice, tobacco, salt, alcoholic beverages, and those supplied at Public Wholesale Market. In rail freight services, entry is allowed subject to approval.

Korea is the least protectionist economy with an overall STRI of 23.1. The highest barriers to trade appear in professional services, more specifically legal advice. Legal advice on domestic law and legal representation in court (mode 3 and 4) are not allowed. Telecommunication is the second sector in importance $(\mathrm{STRI}=50)$. There are some restrictions on fixed-lines and mobile telecommunications. Both types of services are open except for direct facilities-based services, for which the foreign ownership limit is $49 \%$ of the voting shares held by a foreign government or person or deemed foreign person. Constraints in transportation come mainly from rail freight (mode 3). The sector is de facto closed because railroad transportation services are provided exclusively by the Korea Railroad Corporation on railroad routes constructed before July 1, 2005. Services on the railroad routes constructed thereafter are allowed, subject to an economic needs test on the condition of establishing order and discipline in the railroad industry.

\section{CONCLUSIONS}

Several conclusions can be drawn from the foregone analysis. First, countries such as China, Korea, Japan, and the EU impose higher levels of protection on products such as live animals, meat \& edible meat, fish, dairy products, and products of animal origin. This is a fact that may explain the lack of export diversification towards the EAP and the EU regions. It also highlights the potential benefits of diversifying the production structure to more sophisticated and technologically intensive goods, which are less exposed to the effects of trade protection. Second, EAP, mainly China, seems to be more protectionist than the EU, showing more challenges in diversifying towards the first region. In the case of China, more protection translates into higher tariffs, a higher percentage of products affected by at least one NTM, a higher proportion of imports affected by at least one temporary trade barrier, and higher protection on services. And third, although Eurasian countries have concluded a significant amount of regional trade agreements among themselves, few or no RTAs exist between these countries and the EU or those in EAP. We reconcile this in part by the strong preference for regional integration following the dissolution of the Soviet Union. Finally, Eurasia maintains virtually open regimes in services with minor restrictions.

\section{Acknowledgements}

The authors thank Daniel Lederman, Mariem Malouche, José Guilherme Reis, Sebastián Sáez, Gonzalo Varela, and Veronika Zavacka for their helpful comments, and Ahsan Butt for valuable research assistance. Any remaining errors are our responsibility. 


\section{References}

Amiti M., Konings J. (2005) Trade liberalization, intermediate inputs, and productivity: evidence from Indonesia (IMF Working Paper No. WP/05/146). Washington, DC: International Monetary Fund.

Arnold J., Javorcik B., Lipscomb M., Mattoo A. (2012) Services reform and manufacturing performance: evidence from India (Policy Research Working Paper No. 5948). Washington, DC: World Bank.

Asian Development Bank (2006) Central Asia: increasing gains from trade through regional cooperation in trade policy, transport, and customs transit. Manila, Philippines.

Baldwin J.R., Gu W. (2004) Trade liberalization: export-market participation, productivity growth, and innovation." Oxford Review of Economic Policy 29(3), pp. 372-392.

Bas M. (2013) Does services liberalization affect manufacturing firms' export performance? evidence from India (Working Paper 2013-17). Paris: CEPII.

Berulava G. (2011) Services inputs and export performance of manufacturing firms in transition economies (Working Paper Series). Russia: EERC.

Besedina E. (2015) Technical barriers to trade and SPS measures and export dynamics (Working Paper 842). Oslo: Norwegian Institute of International Affairs.

Borchert I. (2007) Preferential trade, sunk costs, and the path-dependent expansion of exports (Department of Economics Working Paper). Switzerland: University of St. Gallen.

Borchert I., Gootiiz B., Mattoo A. (2012a) Guide to the Services Trade Restrictions Database (Policy Research Working Paper No. 6108). Washington, DC: World Bank.

Borchert I., Gootiiz B., Mattoo A. (2012b) Policy barriers to international trade in services: new empirical evidence. (Policy Research Working Paper No. 6109). Washington, DC: World Bank.

Bown C. (2012) Emerging economies and the emergence of South-South protectionism (Policy Research Working Paper No. 6162). Washington, DC: World Bank.

Cadot O., Malouche M., Sàez S. (2012) Streamlining non-tariff measures: a toolkit for policy makers. Washington, DC: World Bank.

Dabaere P., Mostashari S. (2010) Do tariffs matter for the extensive margin of international trade? an empirical analysis. Journal of International Economics 81(2), pp. 163-169.

Ferreira P.C., Rossi J.L. (2003) New evidence from Brazil on trade liberalization and productivity growth." International Economic Review 44(4), pp. 1383-1405.

Gillson I., Reyes J.D. (2011) Harnessing regional integration for trade and growth in Central Asia (International Trade Department). Washington, DC: World Bank.

Gourdon J., Nicita A. (2012) NTMs: interpreting the new data. In O. Cadot, M. Malouch (Eds.), Non-tariff measures: a fresh look at trade policy's new frontier (pp. 57-80). London/Washington, DC: Center for Economic Policy Research/World Bank.

Goldberg P.K., Khandelwal A.K., Pavcnik N., Topalova P. (2010) Imported intermediate inputs and domestic product growth: evidence from India. The Quarterly Journal of Economics 125(4), pp. 1727-1767.

Hillberry R.H., McDaniel C.A. (2002) A decomposition of North American trade growth since NAFTA (Working Paper No. 2002-12-A). Washington, DC: U.S. International Trade Commission.

Kee H.L., Nicita A., Olarreaga M. (2009) Estimating trade restrictiveness indices. The Economic Journal 119, pp. 172-199.

Kehoe T., Ruhl K.J. (2002) How important is the new goods margin in international trade? (Staff Report No. 324). Minneapolis, MN: Federal Reserve Bank of Minneapolis.

Mukerji P. (2009) “Trade liberalization and the extensive margin. Scottish Journal of Political Economy 56, pp. 141-166.

Pavcnik N. (2002) Trade liberalization, exit and productivity improvements: evidence from Chilean plants. Review of Economic Studies 69(1), pp. 245-276.

Rodriguez-Clare A., Klenow P. (1997) Quantifying variety gains from trade liberalization (Graduate School of Business Working Paper) Chicago: University of Chicago.

Sandrey R., Seventer D.V. (2004) Has the New Zealand/Australian Closer Economic Relationship (CER) been trade widening or deepening (Forum Paper 2004)? Somerset West, South Africa: African Development and Poverty Reduction: The Macro-Micro Linkages.

Schor A. (2004) Heterogeneous productivity response to tariff reduction: evidence from Brazilian manufacturing firms. Journal of Development Economics 75(2), pp. 373-396.

Topalova P., Khandelwal A. (2011) Trade liberalization and firm productivity: the case of India. Review of Economics and Statistics 93(3), pp. 995-1009.

Trefler D. (2004) The long and short of the Canada-U.S. Free Trade Agreement. The American Economic Review 94(4), pp. 870-895.

Tybout J.R., Westbrook M.D. (1995) Trade liberalization and the dimensions of the efficiency change in Mexican manufacturing industries. Journal of International Economics (39), pp. 53-78.

World Bank (2011) Russia and Central Asia: win-win approaches in trade integration (ECSPE and the Eurasian Development Bank Center for Integration). Washington, DC: World Bank. 


\section{APPENDIX}

Table 17

Tariffs ${ }^{\mathrm{a}}$

\begin{tabular}{|c|c|c|c|c|c|c|c|c|}
\hline Russia & Product description & Share & China & Indonesia & Japan & Korea & Malaysia & EU \\
\hline 30310 & Frozen Pacific salmon & $7.9 \%$ & 11.05 & 5.00 & 3.96 & 10.10 & 0.00 & 10.00 \\
\hline 30379 & Frozen fish, nes & $39.0 \%$ & 10.00 & 7.50 & 5.02 & 13.12 & 0.00 & 11.02 \\
\hline 30380 & Frozen fish livers and roes & $9.6 \%$ & 10.00 & 2.50 & 3.90 & 10.00 & 0.00 & 6.67 \\
\hline 30420 & Frozen fish fillets & $7.0 \%$ & 10.67 & 10.00 & 3.79 & 13.33 & 0.00 & 15.00 \\
\hline 270112 & Bituminous coal, not agglomerated & $3.2 \%$ & 0.00 & 5.00 & 0.00 & 0.00 & 0.00 & 0.00 \\
\hline 270900 & $\begin{array}{l}\text { Petroleum oils and oils obtained } \\
\text { from bituminou }\end{array}$ & $50.1 \%$ & 0.00 & 0.00 & 0.00 & 3.00 & 2.50 & 0.00 \\
\hline 271000 & $\begin{array}{l}\text { Petroleum oils, etc, (excl. crude); } \\
\text { preparation }\end{array}$ & $27.0 \%$ & 6.00 & 0.39 & 0.87 & 4.34 & 0.19 & 2.77 \\
\hline 271121 & Natural gas in gaseous state & $16.9 \%$ & 0.00 & 5.00 & 4.10 & 2.00 & 0.00 & 0.00 \\
\hline 720712 & $\begin{array}{l}\text { Semifinished products of iron } \\
\text { or nonalloy steel }\end{array}$ & $4.0 \%$ & 2.00 & 0.00 & 0.00 & 0.00 & 0.00 & 0.00 \\
\hline 740311 & $\begin{array}{l}\text { Copper cathodes and sections } \\
\text { of cathodes unwrou }\end{array}$ & $3.4 \%$ & 0.00 & 5.00 & 1.20 & 3.00 & 0.00 & 0.00 \\
\hline 750210 & Nickel unwrought, not alloyed & $5.2 \%$ & 0.00 & 5.00 & 0.00 & 3.00 & 0.00 & 0.00 \\
\hline 760110 & Aluminium unwrought, not alloyed & $4.8 \%$ & 2.50 & 0.00 & 0.00 & 1.00 & 0.00 & 3.00 \\
\hline Belarus & Product description & Share & China & Indonesia & Japan & Korea & Malaysia & $\mathbf{E} \mathbf{U}^{*}$ \\
\hline 40210 & $\begin{array}{l}\text { Milk and cream in solid forms } \\
\text { of }=<1.5 \% \text { fat }\end{array}$ & $10.2 \%$ & 40.00 & 5.00 & 20.00 & 20.00 & 0.00 & b \\
\hline 40500 & $\begin{array}{l}\text { Butter and other fats and oils derived } \\
\text { from mil }\end{array}$ & $14.7 \%$ & 90.00 & 5.00 & 35.00 & 35.00 & 0.00 &.$^{b}$ \\
\hline 70952 & Truffles, fresh or chilled & $27.0 \%$ & 75.00 & 5.00 & 5.16 & 5.16 & 0.00 & 11.55 \\
\hline 81190 & Other fruit and nuts, frozen, nes & $17.2 \%$ & 80.00 & 5.00 & 17.70 & 17.70 & 5.00 & 12.04 \\
\hline 270300 & Peat (incl. peat litter) & $1.0 \%$ & 20.00 & 5.00 & 0.00 & 0.00 & 0.00 & 0.00 \\
\hline 271000 & $\begin{array}{l}\text { Petroleum oils, etc, (excl. crude); } \\
\text { preparation }\end{array}$ & $91.1 \%$ & 19.52 & 0.39 & 1.05 & 1.05 & 0.19 & 2.77 \\
\hline 271112 & Propane, liquefied & $2.9 \%$ & 20.00 & 5.00 & 0.00 & 0.00 & 0.00 & 1.57 \\
\hline 271119 & $\begin{array}{l}\text { Petroleum gases and other gaseous } \\
\text { hydrocarbons, }\end{array}$ & $1.3 \%$ & 50.00 & 5.00 & 2.50 & 2.50 & 0.00 & 0.00 \\
\hline 310420 & Potassium chloride & $27.2 \%$ & 11.00 & 5.00 & 0.00 & 0.00 & 0.00 & 0.00 \\
\hline 720711 & $\begin{array}{l}\text { Semifinished products of iron } \\
\text { or nonalloy steel }\end{array}$ & $3.0 \%$ & 11.00 & 0.00 & 0.00 & 0.00 & 0.00 & 0.00 \\
\hline 721420 & Concrete reinforcing bars and rods & $3.8 \%$ & 20.00 & 10.00 & 3.90 & 3.90 & 11.25 & 0.00 \\
\hline 870190 & Wheeled tractors nes & $5.7 \%$ & 20.00 & 15.00 & 0.00 & 0.00 & 10.00 & 1.00 \\
\hline
\end{tabular}

a The table displays the tariffs imposed by the EU and countries in EAP. The shares reflect the weight of each product within the category to which it belongs. In cases when the tariff at the 6-digit level was not available, we employ the average tariff at 4- or 2-digits.

b no data.

* due to missing values for the EU, the shares of exports are the following: 70952 (42.19\%), $81190(26.89 \%), 71190$ (11.68\%), and 30530 (3.06\% with a tariff of $16.35 \%)$. 


\begin{tabular}{|c|c|c|c|c|c|c|c|c|}
\hline Georgia & Product description & Share & China & Indonesia & Japan & Korea & Malaysia & $\mathbf{E} \mathbf{U}$ \\
\hline 10410 & Live sheep & $7.6 \%$ & 5.00 & 2.50 & 0.00 & 4.00 & 0.00 & 0.00 \\
\hline 80222 & $\begin{array}{l}\text { Hazlenuts without shells, fresh } \\
\text { or dried }\end{array}$ & $46.0 \%$ & 10.00 & 5.00 & 6.00 & 8.00 & 0.00 & 3.20 \\
\hline 80520 & $\begin{array}{l}\text { Mandarins, clementines, } \\
\text { wilkings...etc, fresh o }\end{array}$ & $16.7 \%$ & 12.00 & 20.00 & 17.00 & 144.00 & 5.00 & 16.00 \\
\hline 81090 & Other fruit, fresh, nes & $5.5 \%$ & 20.78 & 5.00 & 5.67 & 160.30 & 16.25 & 7.91 \\
\hline 260300 & Copper ores and concentrates & $15.9 \%$ & 0.00 & 0.00 & 0.00 & 0.00 & 0.00 & 0.00 \\
\hline 270112 & $\begin{array}{l}\text { Bituminous coal, not } \\
\text { agglomerated }\end{array}$ & $4.1 \%$ & 0.00 & 5.00 & 0.00 & 0.00 & 0.00 & 0.00 \\
\hline 270900 & $\begin{array}{l}\text { Petroleum oils and oils obtained } \\
\text { from bituminou }\end{array}$ & $32.3 \%$ & 0.00 & 0.00 & 0.00 & 3.00 & 2.50 & 0.00 \\
\hline 271000 & $\begin{array}{l}\text { Petroleum oils, etc, (excl. crude); } \\
\text { preparation }\end{array}$ & $58.9 \%$ & 6.00 & 0.39 & 0.87 & 4.34 & 0.19 & 2.77 \\
\hline 271600 & Electrical energy & $4.0 \%$ & 0.00 & 0.00 & 0.00 & 5.00 & 0.00 & 0.00 \\
\hline 710812 & $\begin{array}{l}\text { Gold in unwrought forms } \\
\text { non-monetary }\end{array}$ & $8.2 \%$ & 0.00 & 2.50 & 0.00 & 3.00 & 0.00 & 0.00 \\
\hline 720230 & Ferro-silico-manganese & $15.8 \%$ & 2.00 & 0.00 & 2.50 & 5.00 & 0.00 & 3.70 \\
\hline 720449 & $\begin{array}{l}\text { Ferrous waste and scrap, iron } \\
\text { or steel, nes }\end{array}$ & $10.5 \%$ & 0.00 & 0.00 & 0.00 & 0.00 & 0.00 & 0.00 \\
\hline
\end{tabular}

\begin{tabular}{|c|c|c|c|c|c|c|c|c|}
\hline Kazakhstan & Product description & Share & China & Indonesia & Japan & Korea & Malaysia* & $\mathbf{E U}$ \\
\hline 30379 & Frozen fish, nes & $6.4 \%$ & 40.00 & 7.50 & 6.67 & 13.12 & 0.00 & 11.02 \\
\hline 30420 & Frozen fish fillets & $53.9 \%$ & 70.00 & 10.00 & 5.27 & 13.33 & 0.00 & 15.00 \\
\hline 70310 & $\begin{array}{l}\text { Onions and shallots, fresh } \\
\text { or chilled }\end{array}$ & $15.6 \%$ & 70.00 & 6.25 & 5.00 & 81.00 & 0.00 & 9.60 \\
\hline 80710 & Melons and watermelons, fresh & $4.9 \%$ & 70.00 & 5.00 & 8.00 & 40.00 &.$^{b}$ & 6.60 \\
\hline 260112 & $\begin{array}{l}\text { Agglomerated iron ores and } \\
\text { concentrates }\end{array}$ & $5.6 \%$ & 0.00 & 0.00 & 0.00 & 0.00 & 0.00 & 0.00 \\
\hline 270119 & $\begin{array}{l}\text { Other coal, not agglomerated, } \\
\text { nes }\end{array}$ & $10.0 \%$ & 20.00 & 5.00 & 0.00 & 0.00 & 0.00 & 0.00 \\
\hline 271000 & $\begin{array}{l}\text { Petroleum oils, etc, (excl. crude); } \\
\text { preparation }\end{array}$ & $56.2 \%$ & 19.52 & 0.39 & 1.05 & 4.34 & 0.19 & 2.77 \\
\hline 271112 & Propane, liquefied & $11.8 \%$ & 20.00 & 5.00 & 0.00 & 2.00 & 0.00 & 1.57 \\
\hline 271119 & $\begin{array}{l}\text { Petroleum gases and other } \\
\text { gaseous hydrocarbons, }\end{array}$ & $11.2 \%$ & 50.00 & 5.00 & 2.50 & 5.00 & 0.00 & 0.00 \\
\hline 284410 & $\begin{array}{l}\text { Natural uranium and its } \\
\text { compounds, etc }\end{array}$ & $12.1 \%$ & 30.00 & 5.00 & 0.00 & 0.00 & 0.00 & 0.00 \\
\hline 720241 & $\begin{array}{l}\text { Ferro-chromium containing } \\
\text { by weight more than } 4\end{array}$ & $11.2 \%$ & 8.00 & 0.00 & 0.00 & 3.00 & 0.00 & 4.00 \\
\hline 740311 & $\begin{array}{l}\text { Copper cathodes and sections } \\
\text { of cathodes unwrou }\end{array}$ & $15.5 \%$ & 11.00 & 5.00 & 0.00 & 3.00 & 0.00 & 0.00 \\
\hline
\end{tabular}

\footnotetext{
* due to missing data for Malaysia, the shares of exports are the following: $30420(56.7 \%), 70310(16.45 \%), 30379(6.7 \%)$, and $70490(4.5 \%$ with a tariff of $22.5 \%$ ).
} 


\begin{tabular}{|c|c|c|c|c|c|c|c|c|}
\hline Tajikistan & Product description & Share & China & Indonesia & Japan & Korea & Malaysia* & $\mathbf{E U}$ \\
\hline 30420 & Frozen fish fillets & $13.4 \%$ & 70.0 & 10.0 & 5.3 & 13.3 & 0.0 & 15.0 \\
\hline 70310 & $\begin{array}{l}\text { Onions and shallots, fresh } \\
\text { or chilled }\end{array}$ & $23.5 \%$ & 70.0 & 6.3 & 5.0 & 81.0 & 0.0 & 9.6 \\
\hline 81310 & Dried apricots & $22.4 \%$ & 70.0 & 5.0 & 15.0 & 45.0 & 5.0 & 5.6 \\
\hline 81350 & $\begin{array}{l}\text { Mixtures of dried fruit } \\
\text { and nuts, nes }\end{array}$ & $18.6 \%$ & 70.0 & 5.0 & 15.0 & 45.0 & 10.4 & 7.2 \\
\hline 270300 & Peat (incl. peat litter) & $90.7 \%$ & 20.0 & 5.0 & 0.0 & 1.0 & 0.0 & 0.0 \\
\hline 271000 & $\begin{array}{l}\text { Petroleum oils, etc, } \\
\text { (excl. crude); preparation }\end{array}$ & $0.4 \%$ & 19.5 & 0.4 & 1.0 & 4.3 & 0.2 & 2.8 \\
\hline 271121 & Natural gas in gaseous state & $6.8 \%$ & 20.0 & 5.0 & 5.0 & 2.0 & 0.0 & 0.0 \\
\hline 271600 & Electrical energy & $2.1 \%$ & 8.0 & 0.0 & $\mathrm{~b}$ & 5.0 & 0.0 & 0.0 \\
\hline 520100 & Cotton, not carded or combed & $16.0 \%$ & 125.0 & 0.0 & 0.0 & 0.0 & 0.0 & 0.0 \\
\hline 620342 & $\begin{array}{l}\text { Men's or boys' trousers, } \\
\text { breeches, etc, of cott }\end{array}$ & $1.7 \%$ & 90.0 & 15.0 & 13.6 & 13.0 & 20.0 & 12.0 \\
\hline 760110 & $\begin{array}{l}\text { Aluminium unwrought, not } \\
\text { alloyed }\end{array}$ & $60.4 \%$ & 14.0 & 0.0 & 0.0 & 1.0 & 0.0 & 3.0 \\
\hline 760120 & Aluminium unwrought, alloyed & $7.4 \%$ & 14.0 & 0.0 & 0.0 & 1.7 & 0.0 & 6.0 \\
\hline
\end{tabular}

\begin{tabular}{|c|c|c|c|c|c|c|c|c|}
\hline Kyrgyz Rep. & Product description & Share & China & Indonesia & $\operatorname{Japan}^{* *}$ & Korea & Malaysia & $\mathbf{E U}$ \\
\hline 71333 & $\begin{array}{l}\text { Dried kidney beans, incl. } \\
\text { white pea beans, shel }\end{array}$ & $16.7 \%$ & 3.8 & 2.5 & 5.3 & 27.0 & 0.0 & 0.0 \\
\hline 80610 & Fresh grapes & $10.6 \%$ & 13.0 & 5.0 & 1.2 & 45.0 & 5.0 & 12.5 \\
\hline 80910 & Apricots, fresh & $8.1 \%$ & 25.0 & 5.0 & 6.0 & 45.0 & 5.0 & 12.0 \\
\hline 80920 & Cherries, fresh & $13.1 \%$ & 10.0 & 5.0 & 8.5 & 24.0 & 5.0 & 12.0 \\
\hline 270112 & $\begin{array}{l}\text { Bituminous coal, not } \\
\text { agglomerated }\end{array}$ & $1.5 \%$ & 0.0 & 5.0 & 0.0 & 0.0 & 0.0 & 0.0 \\
\hline 270900 & $\begin{array}{l}\text { Petroleum oils and oils } \\
\text { obtained from bituminou }\end{array}$ & $20.6 \%$ & 0.0 & 0.0 & 0.0 & 3.0 & 2.5 & 0.0 \\
\hline 271000 & $\begin{array}{l}\text { Petroleum oils, etc, } \\
\text { (excl. crude); preparation }\end{array}$ & $75.3 \%$ & 6.0 & 0.4 & 0.9 & 4.3 & 0.2 & 2.8 \\
\hline 271600 & Electrical energy & $2.0 \%$ & 0.0 & 0.0 &.${ }^{\mathrm{b}}$ & 5.0 & 0.0 & 0.0 \\
\hline 284410 & $\begin{array}{l}\text { Natural uranium and its } \\
\text { compounds, etc }\end{array}$ & $36.8 \%$ & 5.5 & 5.0 & 0.0 & 0.0 & 0.0 & 0.0 \\
\hline 620343 & $\begin{array}{l}\text { Men's or boys' trousers, } \\
\text { breeches of synthetic }\end{array}$ & $3.7 \%$ & 17.5 & 15.0 & 9.6 & 13.0 & 20.0 & 12.0 \\
\hline 620640 & $\begin{array}{l}\text { Women's or girls' blouses, } \\
\text { shirts, etc, of man- }\end{array}$ & $5.8 \%$ & 17.5 & 15.0 & 8.8 & 13.0 & 20.0 & 12.0 \\
\hline 740400 & $\begin{array}{l}\text { Waste and scrap, copper } \\
\text { or copper alloy }\end{array}$ & $4.6 \%$ & 0.0 & 0.0 & 0.0 & 0.0 & 0.0 & 0.0 \\
\hline
\end{tabular}




\begin{tabular}{|c|c|c|c|c|c|c|c|c|}
\hline Moldova & Product description & Share & China & Indonesia & Japan* $^{*}$ & Korea & Malaysia & $\mathbf{E U}$ \\
\hline 80232 & $\begin{array}{l}\text { Walnuts without shells, fresh } \\
\text { or dried }\end{array}$ & $25.2 \%$ & 20.0 & 5.0 & 10.0 & 30.0 & 0.0 & 5.1 \\
\hline 80610 & Fresh grapes & $10.6 \%$ & 13.0 & 5.0 & 1.2 & 45.0 & 5.0 & 12.5 \\
\hline 80810 & Apples, fresh & $33.0 \%$ & 10.0 & 5.0 & 17.0 & 45.0 & 5.0 & 7.2 \\
\hline 80940 & Plums and sloes, fresh & $6.8 \%$ & 10.0 & 5.0 & 6.0 & 45.0 & 5.0 & 12.0 \\
\hline 120600 & Sunflower seeds & $3.9 \%$ & 7.5 & 5.0 & 0.0 & 25.0 & 0.0 & 0.0 \\
\hline 220421 & $\begin{array}{l}\text { Wine (not sparkling); grape } \\
\text { must with by alcoh. }\end{array}$ & $5.0 \%$ & 14.0 &.$^{\mathrm{b}}$ & 15.0 & 15.0 &.$^{b}$ & 32.0 \\
\hline 271000 & $\begin{array}{l}\text { Petroleum oils, etc, } \\
\text { (excl. crude); preparation }\end{array}$ & $11.8 \%$ & 6.0 & 0.4 & 0.9 & 4.3 & 0.2 & 2.8 \\
\hline 271113 & Butanes, liquefied & $3.4 \%$ & 8.0 & 5.0 & 0.0 & 2.0 & 0.0 & 0.4 \\
\hline 271114 & $\begin{array}{l}\text { Ethylene, propylene, } \\
\text { butylene and butadiene, li }\end{array}$ & $0.0 \%$ & 5.0 & 2.5 & 0.0 & 5.0 & 0.0 & 0.0 \\
\hline 271600 & Electrical energy & $84.7 \%$ & 0.0 & 0.0 &.$^{b}$ & 5.0 & 0.0 & 0.0 \\
\hline 721331 & $\begin{array}{l}\text { Bars and Rods Of circular } \\
\text { cross section }\end{array}$ & $5.8 \%$ & 4.0 & 7.1 & 0.0 & 0.0 & 15.0 & 0.0 \\
\hline 854430 & $\begin{array}{l}\text { Ignition wiring sets\&oth } \\
\text { wiring sets of a kind }\end{array}$ & $3.5 \%$ & 7.5 & 10.0 & 2.4 & 8.0 & 21.7 & 1.9 \\
\hline
\end{tabular}

\begin{tabular}{|c|c|c|c|c|c|c|c|c|}
\hline Uzbekistan & Product description & Share & China & Indonesia & Japan & Korea & Malaysia** $^{* *}$ & EU $\mathbf{U}^{\mathrm{g}}$ \\
\hline 70200 & Tomatoes, fresh or chilled & $12.2 \%$ & 70.0 & 5.0 & 5.0 & 45.0 & 0.0 &. $\mathrm{~b}$ \\
\hline 80610 & Fresh grapes & $11.9 \%$ & 80.0 & 5.0 & 2.0 & 45.0 & 5.0 & 12.5 \\
\hline 80710 & Melons and watermelons, fresh & $11.9 \%$ & 70.0 & 5.0 & 8.0 & 40.0 & $\mathrm{~b}$ & 6.6 \\
\hline 81090 & Other fruit, fresh, nes & $10.1 \%$ & 80.0 & 5.0 & 10.0 & 160.3 & 16.3 & 7.9 \\
\hline 270300 & Peat (incl. peat litter) & $73.2 \%$ & 20.0 & 5.0 & 0.0 & 1.0 & 0.0 & 0.0 \\
\hline 271000 & $\begin{array}{l}\text { Petroleum oils, etc, (excl. } \\
\text { crude); preparation }\end{array}$ & $15.2 \%$ & 19.5 & 0.4 & 1.0 & 4.3 & 0.2 & 2.8 \\
\hline 271121 & Natural gas in gaseous state & $7.9 \%$ & 20.0 & 5.0 & 5.0 & 2.0 & 0.0 & 0.0 \\
\hline 271290 & $\begin{array}{l}\text { Other paraffin wax... and } \\
\text { similar products, nes }\end{array}$ & $2.3 \%$ & 45.0 & 2.5 & 3.2 & 8.0 & 0.0 & 0.6 \\
\hline 284410 & $\begin{array}{l}\text { Natural uranium and its } \\
\text { compounds, etc }\end{array}$ & $14.6 \%$ & 30.0 & 5.0 & 0.0 & 0.0 & 0.0 & 0.0 \\
\hline 520100 & Cotton, not carded or combed & $22.2 \%$ & 125.0 & 0.0 & 0.0 & 0.0 & 0.0 & 0.0 \\
\hline 710812 & $\begin{array}{l}\text { Gold in unwrought forms } \\
\text { non-monetary }\end{array}$ & $4.2 \%$ & 0.0 & 2.5 & 0.0 & 3.0 & 0.0 & 0.0 \\
\hline 740311 & $\begin{array}{l}\text { Copper cathodes and sections } \\
\text { of cathodes unwrou }\end{array}$ & $10.7 \%$ & 11.0 & 5.0 & 0.0 & 3.0 & 0.0 & 0.0 \\
\hline
\end{tabular}

* due to missing data for Japan, the shares of exports are the following: $271000(77.2 \%), 271113(22.37 \%)$, and $271114(0.31 \%)$. Due to missing values for Indonesia and Malaysia, the share of exports are the following: $721331(6.7 \%), 120600(4.5 \%), 854430(4.05 \%)$, and $640399(3.59 \%)$.

** due to missing data for Malaysia, the shares of exports are the following: $70200(13.8 \%), 80610(13.5 \%), 81090$ (11.4\% with a tariff of $16.25 \%)$, and $809105(5 \%$ with a tariff of $7.2 \%)$. Due to missing data for the EU, the shares of exports are the following: 80610 (13.6\%), 80710 $(13.5 \%), 81090(11.5 \%)$, and $80910(7.3 \%)$. 


\begin{tabular}{|c|c|c|c|c|c|c|c|c|}
\hline Turkmenistan & Product description & Share & China & Indonesia & Japan* & Korea & Malaysia & $\mathbf{E U}$ \\
\hline 50400 & $\begin{array}{l}\text { Guts, bladders and stomachs } \\
\text { of animals (excl. f }\end{array}$ & $34.1 \%$ & 88.57 & 5.00 & 0.00 & 27.00 & 0.00 & 0.00 \\
\hline 70700 & $\begin{array}{l}\text { Cucumbers and gherkins, } \\
\text { fresh or chilled }\end{array}$ & $11.1 \%$ & 70.00 & 5.00 & 5.00 & 27.00 & 0.00 & 12.80 \\
\hline 80610 & Fresh grapes & $20.8 \%$ & 80.00 & 5.00 & 2.00 & 45.00 & 5.00 & 12.47 \\
\hline 80810 & Apples, fresh & $17.4 \%$ & 100.00 & 5.00 & 20.00 & 45.00 & 5.00 & 7.20 \\
\hline 270300 & Peat (incl. peat litter) & $5.8 \%$ & 20.00 & 5.00 & 0.00 & 1.00 & 0.00 & 0.00 \\
\hline 271000 & $\begin{array}{l}\text { Petroleum oils, etc, } \\
\text { (excl. crude); preparation }\end{array}$ & $35.2 \%$ & 19.52 & 0.39 & 1.05 & 4.34 & 0.19 & 2.77 \\
\hline 271121 & Natural gas in gaseous state & $56.5 \%$ & 20.00 & 5.00 & 5.00 & 2.00 & 0.00 & 0.00 \\
\hline 271600 & Electrical energy & $1.0 \%$ & 8.00 & 0.00 & b & 5.00 & 0.00 & 0.00 \\
\hline 390210 & $\begin{array}{l}\text { Polypropylene, in primary } \\
\text { forms }\end{array}$ & $12.9 \%$ & 45.00 & 15.00 & $\mathrm{~b}$ & 6.50 & 6.67 & 6.50 \\
\hline 520100 & Cotton, not carded or combed & $33.3 \%$ & 125.00 & 0.00 & 0.00 & 0.00 & 0.00 & 0.00 \\
\hline 520512 & $\begin{array}{l}\text { Uncombed single cotton yarn, } \\
\text { with }>=85 \% \text { cotton, }\end{array}$ & $15.1 \%$ & 40.00 & 5.00 & 4.20 & 6.67 & 10.00 & 4.00 \\
\hline 520812 & $\begin{array}{l}\text { Unbleached plain cotton } \\
\text { weave, with }>=85 \% \text { cotto }\end{array}$ & $5.4 \%$ & 70.00 & 10.00 & 5.60 & 10.00 & 10.00 & 8.00 \\
\hline Azerbaijan & Product description & Share & China & Indonesia & Japan & Korea & Malaysia & $\mathbf{E} \mathbf{U}^{* *}$ \\
\hline 70190 & Other potatoes, fresh or chilled & $9 \%$ & 70.00 & 20.00 & 5.00 & 304.00 & 0.00 & 9.60 \\
\hline 70200 & Tomatoes, fresh or chilled & $12 \%$ & 70.00 & 5.00 & 5.00 & 45.00 & 0.00 & $\mathrm{~b}$ \\
\hline 80222 & $\begin{array}{l}\text { Hazlenuts without shells, } \\
\text { fresh or dried }\end{array}$ & $19 \%$ & 70.00 & 5.00 & 10.00 & 8.00 & 0.00 & 3.20 \\
\hline 81090 & Other fruit, fresh, nes & $41 \%$ & 80.00 & 5.00 & 10.00 & 160.30 & 16.25 & 7.91 \\
\hline 271000 & $\begin{array}{l}\text { Petroleum oils, etc, } \\
\text { (excl. crude); preparation }\end{array}$ & $72 \%$ & 19.52 & 0.39 & 1.05 & 4.34 & 0.19 & 2.77 \\
\hline 271119 & $\begin{array}{l}\text { Petroleum gases and other } \\
\text { gaseous hydrocarbons, }\end{array}$ & $7 \%$ & 50.00 & 5.00 & 2.50 & 5.00 & 0.00 & 0.00 \\
\hline 271121 & Natural gas in gaseous state & $8 \%$ & 20.00 & 5.00 & 5.00 & 2.00 & 0.00 & 0.00 \\
\hline 271311 & Petroleum coke, not calcined & $6 \%$ & 11.00 & 5.00 & 0.00 & 5.00 & 0.00 & 0.00 \\
\hline 390110 & $\begin{array}{l}\text { Polyethylene having a specific } \\
\text { gravity }<0.94, \text { i }\end{array}$ & $9 \%$ & 45.00 & 11.67 & 4.10 & 6.50 & 20.00 & 6.50 \\
\hline 440710 & $\begin{array}{l}\text { Coniferous wood sawn } \\
\text { or chipped lengthwise, sli }\end{array}$ & $6 \%$ & 14.00 & 0.00 & 1.67 & 5.00 & 0.00 & 0.00 \\
\hline 711319 & $\begin{array}{l}\text { Art. of jewellery and pts } \\
\text { thereof of/o prec mtl }\end{array}$ & $5 \%$ & 130.00 & 10.00 & 6.47 & 8.00 & 10.00 & 2.50 \\
\hline 721631 & $\begin{array}{l}\text { U sections, not further worked } \\
\text { than hot-rolled, hot-drawn or } \\
\text { extruded, of a height of } 80 \mathrm{~mm}\end{array}$ & $7 \%$ & 14.00 & 15.00 & 3.90 & 0.00 & 20.00 & 0.00 \\
\hline
\end{tabular}

\footnotetext{
* due to missing data for Japan, the shares of exports are the following: 271120 (54.4\%), 271000 (33.8\%), 270300 (4.1\%), and $270900(3.5 \%$ with a tariff of $0 \%$ ).

** due to missing data for the EU, the shares of exports are the following: $81090(46.4 \%), 80222$ (21.65\%), $70190(9.9 \%), 80810(9.65 \%$ with a tariff of $7.2 \%$ ).
} 


\begin{tabular}{|c|c|c|c|c|c|c|c|c|}
\hline Armenia & Product description & Share & China & Indonesia* & Japan & Korea & Malaysia* & $\mathbf{E U}$ \\
\hline 10410 & Live sheep & $54.3 \%$ & 5.00 & 2.50 & 0.00 & 4.00 & 0.00 & 0.00 \\
\hline 30379 & Frozen fish, nes & $3.7 \%$ & 10.00 & 7.50 & 5.02 & 13.12 & 0.00 & 11.02 \\
\hline 30629 & $\begin{array}{l}\text { Crustaceans not } \\
\text { frozen,nes, includ.flours,meals, }\end{array}$ & $10.4 \%$ & 7.00 & 5.00 & 6.00 & 20.00 & 4.00 & 10.88 \\
\hline 80610 & Fresh grapes & $11.6 \%$ & 13.00 & 5.00 & 1.60 & 45.00 & 5.00 & 12.47 \\
\hline 220820 & $\begin{array}{l}\text { Spirits from distilled grape } \\
\text { wine or marc }\end{array}$ & $13.3 \%$ & 10.00 & $\mathrm{~b}^{\mathrm{b}}$ & 0.00 & 15.00 & ${ }^{b}$ & 0.00 \\
\hline 271112 & Propane, liquefied & $0.5 \%$ & 5.00 & 5.00 & 0.00 & 2.00 & 0.00 & 1.57 \\
\hline 271113 & Butanes, liquefied & $0.5 \%$ & 8.00 & 5.00 & 0.00 & 2.00 & 0.00 & 0.35 \\
\hline 271119 & $\begin{array}{l}\text { Petroleum gases and other } \\
\text { gaseous hydrocarbons, }\end{array}$ & $5.6 \%$ & 6.50 & 5.00 & 2.05 & 5.00 & 0.00 & 0.00 \\
\hline 271121 & Natural gas in gaseous state & $92.8 \%$ & 0.00 & 5.00 & 4.10 & 2.00 & 0.00 & 0.00 \\
\hline 720270 & Ferro-molybdenum & $15.0 \%$ & 2.00 & 0.00 & 3.30 & 3.00 & 0.00 & 2.70 \\
\hline 740200 & $\begin{array}{l}\text { Copper unrefined, copper } \\
\text { anodes for electrolyti }\end{array}$ & $9.8 \%$ & 0.00 & 5.00 & 0.00 & 0.00 & 0.00 & 0.00 \\
\hline 760711 & $\begin{array}{l}\text { Foil, aluminium, not backed, } \\
\text { rolled but not fur }\end{array}$ & $10.6 \%$ & 6.00 & 20.00 & 7.50 & 8.00 & 25.00 & 7.50 \\
\hline Ukraine & Product description & Share & China & Indonesia & Japan & Korea & Malaysia & $\mathbf{E} \mathbf{U}^{* *}$ \\
\hline 40690 & Cheese, nes & $40.2 \%$ & 12.0 & 5.0 & 14.9 & 36.0 & 0.0 & 7.7 \\
\hline 70200 & Tomatoes, fresh or chilled & $5.4 \%$ & 13.0 & 5.0 & 3.0 & 45.0 & 0.0 &.$^{b}$ \\
\hline 80232 & $\begin{array}{l}\text { Walnuts without shells, fresh } \\
\text { or dried }\end{array}$ & $9.1 \%$ & 20.0 & 5.0 & 10.0 & 30.0 & 0.0 & 5.1 \\
\hline 81190 & Other fruit and nuts, frozen, nes & $6.9 \%$ & 30.0 & 5.0 & 12.2 & 30.0 & 5.0 & 15.1 \\
\hline 151211 & $\begin{array}{l}\text { Crude sunflower-seed and } \\
\text { safflower oil and frac }\end{array}$ & $4.3 \%$ & 9.0 & 5.0 & 0.0 & 9.0 & 0.0 & 5.3 \\
\hline 260111 & $\begin{array}{l}\text { Non-agglomerated iron ores } \\
\text { and concentrates }\end{array}$ & $5.1 \%$ & 0.0 & 0.0 & 0.0 & 0.0 & 0.0 & 0.0 \\
\hline 260112 & $\begin{array}{l}\text { Agglomerated iron ores and } \\
\text { concentrates }\end{array}$ & $2.5 \%$ & 0.0 & 0.0 & 0.0 & 0.0 & 0.0 & 0.0 \\
\hline 270111 & Anthracite, not agglomerated & $13.2 \%$ & 0.0 & 5.0 & 0.0 & 0.0 & 0.0 & 0.0 \\
\hline 270400 & $\begin{array}{l}\text { Coke and semi-coke of coal, } \\
\text { of lignite or of pe }\end{array}$ & $8.3 \%$ & 0.0 & 0.0 & 1.6 & 3.0 & 0.0 & 0.0 \\
\hline 270900 & $\begin{array}{l}\text { Petroleum oils and oils } \\
\text { obtained from bituminou }\end{array}$ & $5.9 \%$ & 0.0 & 0.0 & 0.0 & 3.0 & 2.5 & 0.0 \\
\hline 271000 & $\begin{array}{l}\text { Petroleum oils, etc, (excl. } \\
\text { crude); preparation }\end{array}$ & $57.9 \%$ & 19.5 & 0.4 & 1.0 & 4.3 & 0.2 & 2.8 \\
\hline 720712 & $\begin{array}{l}\text { Semi-fin prod,iron or n-al } \\
\text { steel,rect/ sq cross }\end{array}$ & $6.0 \%$ & 2.0 & 0.0 & 0.0 & 0.0 & 0.0 & 0.0 \\
\hline
\end{tabular}

* due to missing data for Indonesia and Malaysia, the shares of exports are the following: 720270 (17.5\%0), 760711 (12.4\%), 740200 (11.4\%), $260300(8.6 \%$ with a tariff of $0 \%)$.

** due to missing data for the EU, the shares of exports are the following: $40690(48.6 \%), 80232(11.1 \%), 81190(8.4 \%)$, and $71310(5.8 \%$ with a tariff of $0 \%$ ).

Source: Authors' calculations using tariff data from UNCTAD and trade data from UN Comtrade accessed through WITS (2012). 
Table 18

Plurilateral and Bilateral Trade Agreements of Eurasian Countries

\begin{tabular}{|c|c|c|c|c|}
\hline $\begin{array}{c}\text { Trade agreement } \\
\text { name }\end{array}$ & $\begin{array}{l}\text { Date of entry } \\
\text { into force }\end{array}$ & Current signatories & In force & $\begin{array}{l}\text { Notified } \\
\text { to WTO }\end{array}$ \\
\hline
\end{tabular}

\section{Plurilateral:}

\begin{tabular}{|c|c|c|c|c|}
\hline $\begin{array}{l}\text { Commonwealth of } \\
\text { Independent States } \\
(\mathrm{CIS})^{\mathrm{a}}\end{array}$ & 1994 & $\begin{array}{l}\text { Armenia, Azerbaijan, Belarus, Georgia, } \\
\text { Kazakhstan, Kyrgyzstan, Moldova, Russian } \\
\text { Federation, Tajikistan, Turkmenistan, Ukraine, } \\
\text { Uzbekistan }\end{array}$ & Y & Y \\
\hline $\begin{array}{l}\text { Economic } \\
\text { Cooperation } \\
\text { Organization (ECO) }\end{array}$ & 1992 & $\begin{array}{l}\text { Afghanistan, Azerbaijan, Iran, Kazakhstan, } \\
\text { Kyrgyzstan, Pakistan, Tajikistan, Turkey, } \\
\text { Turkmenistan, Uzbekistan }\end{array}$ & $\mathrm{Y}$ & $\mathrm{Y}$ \\
\hline $\begin{array}{l}\text { Common Economic } \\
\text { Zone }(\mathrm{CEZ})^{\mathrm{a}}\end{array}$ & 2004 & $\begin{array}{l}\text { Belarus, Kazakhstan, Russian Federation, } \\
\text { Ukraine }\end{array}$ & $\mathrm{Y}$ & $\mathrm{Y}$ \\
\hline $\begin{array}{l}\text { Eurasian Economic } \\
\text { Community }(\text { EAEC) })^{\mathrm{a}}\end{array}$ & 1997 & $\begin{array}{l}\text { Belarus, Kazakhstan, Kyrgyzstan, Russian } \\
\text { Federation, Tajikistan }\end{array}$ & Y & $\mathrm{Y}$ \\
\hline $\begin{array}{l}\text { Central European } \\
\text { FTA (CEFTA) }\end{array}$ & 2007 & $\begin{array}{l}\text { Albania, Bosnia and Herzegovina, Croatia, } \\
\text { Former Yugoslav Republic of Macedonia, } \\
\text { Moldova, Montenegro, Serbia, UNMIK/Kosovo }\end{array}$ & $\mathrm{Y}$ & $\mathrm{Y}$ \\
\hline GUUAM $^{\mathrm{a}}$ & n.a. ${ }^{b}$ & $\begin{array}{l}\text { Azerbaijan, Georgia, Moldova, Uzbekistan, } \\
\text { Ukraine }\end{array}$ & $\mathrm{Y}$ & $\mathrm{N}$ \\
\hline $\begin{array}{l}\text { European } \\
\text { Community- } \\
\text { Overseas Countries } \\
\text { and Territories } \\
\text { (EC-OCT) }\end{array}$ & 1971 & $\begin{array}{l}\text { European Community, Anguilla, Aruba, } \\
\text { British Indian Ocean Territory, Cayman } \\
\text { Islands, Falkland Islands (Islas Malvinas), } \\
\text { French Polynesia, French Southern Territories, } \\
\text { Greenland, Mayotte, Montserrat, Netherlands } \\
\text { Antilles, New Caledonia, Pitcairn, Saint Helena, } \\
\text { Saint Pierre and Miquelon, South Georgia and } \\
\text { the South Sandwich Islands, Turks and Caicos } \\
\text { Islands, Virgin Islands, British, Wallis and } \\
\text { Futuna Islands }\end{array}$ & $\mathrm{Y}$ & $\mathrm{Y}$ \\
\hline $\begin{array}{l}\text { Moldova- } \\
\text { Montenegro-Serbia }\end{array}$ & n.a. ${ }^{b}$ & & n.a. ${ }^{b}$ & $\mathrm{~N}$ \\
\hline Ukraine-EFTA & 2012 & $\begin{array}{l}\text { Iceland, Liechtenstein, Norway, Switzerland, } \\
\text { Ukraine }\end{array}$ & $\mathrm{Y}$ & $\mathrm{Y}$ \\
\hline $\begin{array}{l}\text { Free Trade } \\
\text { Agreement between } \\
\text { members of the } \\
\text { Commonwealth of } \\
\text { Independent States } \\
\text { (CIS) }\end{array}$ & $-^{\mathrm{c}}$ & $\begin{array}{l}\text { Armenia, Belarus, Kazakhstan, Kyrgyzstan, } \\
\text { Moldova, Russian Federation, Tajikistan, } \\
\text { Ukraine }\end{array}$ & $\begin{array}{c}\text { Early } \\
\text { Announcement }\end{array}$ & $\mathrm{Y}$ \\
\hline $\begin{array}{l}\text { EFTA-Russian } \\
\text { Federation/Belarus/ } \\
\text { Kazakhstan }\end{array}$ & $-^{\mathrm{c}}$ & $\begin{array}{l}\text { Iceland, Liechtenstein, Norway, Switzerland, } \\
\text { Russian Federation, Belarus, Kazakhstan }\end{array}$ & $\begin{array}{c}\text { Early } \\
\text { Announcement }\end{array}$ & $\mathrm{Y}$ \\
\hline Ukraine-EU & $-^{\mathrm{c}}$ & & $\begin{array}{c}\text { Early } \\
\text { Announcement }\end{array}$ & $\mathrm{Y}$ \\
\hline \multicolumn{5}{|l|}{ Bilateral: } \\
\hline $\begin{array}{l}\text { Armenia- } \\
\text { Kazakhstan }^{\mathrm{a}}\end{array}$ & 2001 & & $\mathrm{Y}$ & $\mathrm{Y}$ \\
\hline
\end{tabular}




\begin{tabular}{|c|c|c|c|c|}
\hline $\begin{array}{c}\text { Trade agreement } \\
\text { name }\end{array}$ & $\begin{array}{l}\text { Date of entry } \\
\text { into force }\end{array}$ & Current signatories & In force & $\begin{array}{l}\text { Notified } \\
\text { to WTO }\end{array}$ \\
\hline Armenia-Moldova ${ }^{a}$ & 1995 & & $\mathrm{Y}$ & $\mathrm{Y}$ \\
\hline $\begin{array}{l}\text { Armenia-Russian } \\
\text { Federation }^{\text {a }}\end{array}$ & 1993 & & $\mathrm{Y}$ & $\mathrm{Y}$ \\
\hline $\begin{array}{l}\text { Armenia- } \\
\text { Turkmenistan }^{\mathrm{a}}\end{array}$ & 1996 & & Y & $\mathrm{Y}$ \\
\hline Armenia-Ukraine $^{\mathrm{a}}$ & 1996 & & Y & $\mathrm{Y}$ \\
\hline Armenia-Georgia $^{a}$ & 1998 & & Y & $\mathrm{Y}$ \\
\hline Armenia-Iran & 1997 & & Expired & $\mathrm{N}$ \\
\hline $\begin{array}{l}\text { Armenia- } \\
\text { Kyrgyzstan }^{\mathrm{a}}\end{array}$ & 1995 & & $\mathrm{Y}$ & $\mathrm{Y}$ \\
\hline Azerbaijan-Georgia ${ }^{a}$ & 1996 & & Y & $\mathrm{Y}$ \\
\hline $\begin{array}{l}\text { Azerbaijan-Russian } \\
\text { Federation }^{\mathrm{a}}\end{array}$ & 1993 & & n.a. ${ }^{b}$ & $\mathrm{Y}$ \\
\hline Azerbaijan-Ukraine ${ }^{a}$ & 1996 & & Y & $\mathrm{Y}$ \\
\hline $\begin{array}{l}\text { Belarus-Russian } \\
\text { Federation }^{\mathrm{a}}\end{array}$ & 1993 & & n.a. ${ }^{b}$ & $\mathrm{Y}$ \\
\hline Belarus-Ukraine ${ }^{\mathrm{a}}$ & 2006 & & Y & $\mathrm{Y}$ \\
\hline Georgia-Kazakhstan ${ }^{\mathrm{a}}$ & 1999 & & Y & $\mathrm{Y}$ \\
\hline $\begin{array}{l}\text { Georgia-Russian } \\
\text { Federation }^{\mathrm{a}}\end{array}$ & 1994 & & $\mathrm{Y}$ & $\mathrm{Y}$ \\
\hline $\begin{array}{l}\text { Georgia- } \\
\text { Turkmenistan }^{\text {a }}\end{array}$ & 2000 & & Y & $\mathrm{Y}$ \\
\hline Georgia-Ukraine $^{a}$ & 1996 & & Y & $\mathrm{Y}$ \\
\hline Georgia-Turkey & 2008 & & $\mathrm{Y}$ & $\mathrm{Y}$ \\
\hline $\begin{array}{l}\text { Kazakhstan- } \\
\text { Kyrgyzstan }^{\mathrm{a}}\end{array}$ & 1995 & & $\mathrm{Y}$ & $\mathrm{Y}$ \\
\hline $\begin{array}{l}\text { Kazakhstan-Russian } \\
\text { Federation }^{\mathrm{a}}\end{array}$ & 1993 & & n.a. ${ }^{b}$ & Y \\
\hline Kazakhstan-Ukraine ${ }^{\mathrm{a}}$ & 1998 & & Y & $\mathrm{Y}$ \\
\hline $\begin{array}{l}\text { Kyrgyzstan- } \\
\text { Moldova }^{\mathrm{a}}\end{array}$ & 1996 & & Y & $\mathrm{Y}$ \\
\hline $\begin{array}{l}\text { Kyrgyzstan-Russian } \\
\text { Federation }^{\mathrm{a}}\end{array}$ & 1993 & & Y & $\mathrm{Y}$ \\
\hline Kyrgyzstan-Ukraine ${ }^{\mathrm{a}}$ & 1998 & & Y & $\mathrm{Y}$ \\
\hline $\begin{array}{l}\text { Kyrgyzstan- } \\
\text { Uzbekistan }^{\text {a }}\end{array}$ & 1998 & & Y & $\mathrm{Y}$ \\
\hline Moldova-Albania & n.a. ${ }^{b}$ & & n.a. ${ }^{b}$ & $\mathrm{~N}$ \\
\hline $\begin{array}{l}\text { Moldova-Bosnia and } \\
\text { Herzegovina }\end{array}$ & n.a. ${ }^{b}$ & & Y & $\mathrm{N}$ \\
\hline Moldova-Croatia & 2004 & & Y & $\mathrm{Y}$ \\
\hline
\end{tabular}




\begin{tabular}{|c|c|c|c|c|}
\hline $\begin{array}{c}\text { Trade agreement } \\
\text { name }\end{array}$ & $\begin{array}{l}\text { Date of entry } \\
\text { into force }\end{array}$ & Current signatories & In force & $\begin{array}{l}\text { Notified } \\
\text { to WTO }\end{array}$ \\
\hline $\begin{array}{l}\text { Moldova- } \\
\text { Macedonia, FYR }\end{array}$ & 2004 & & Y & $\mathrm{Y}$ \\
\hline Moldova-Romania ${ }^{a}$ & 1995 & & $\mathrm{Y}$ & $\mathrm{Y}$ \\
\hline $\begin{array}{l}\text { Moldova-Russian } \\
\text { Federation }^{\text {a }}\end{array}$ & 1993 & & n.a. ${ }^{b}$ & $\mathrm{Y}$ \\
\hline Moldova-Ukraine $^{\mathrm{a}}$ & 2005 & & Y & $\mathrm{Y}$ \\
\hline $\begin{array}{l}\text { Russian Federation- } \\
\text { New Zealand }\end{array}$ & $-^{\mathrm{c}}$ & & $\begin{array}{c}\text { Early } \\
\text { Announcement }\end{array}$ & $\mathrm{Y}$ \\
\hline $\begin{array}{l}\text { Russian Federation- } \\
\text { Tajikistan }^{\mathrm{a}}\end{array}$ & 1993 & & n.a. ${ }^{b}$ & $\mathrm{Y}$ \\
\hline $\begin{array}{l}\text { Russian } \\
\text { Federation-Ukraine }^{a}\end{array}$ & 1994 & & Y & $\mathrm{Y}$ \\
\hline Tajikistan-Ukraine ${ }^{a}$ & 2002 & & $\mathrm{Y}$ & $\mathrm{Y}$ \\
\hline $\begin{array}{l}\text { Turkmenistan- } \\
\text { Ukraine }^{\mathrm{a}}\end{array}$ & 1995 & & $\mathrm{Y}$ & $\mathrm{Y}$ \\
\hline Ukraine-Canada & $-^{\mathrm{c}}$ & & $\begin{array}{c}\text { Early } \\
\text { Announcement }\end{array}$ & $\mathrm{Y}$ \\
\hline Ukraine-Estonia & 1996 & & Expired & $\mathrm{y}$ \\
\hline $\begin{array}{l}\text { Ukraine-Macedonia, } \\
\text { FYR }\end{array}$ & 2001 & & $\mathrm{Y}$ & $\mathrm{Y}$ \\
\hline Ukraine-Singapore & $-^{c}$ & & $\begin{array}{c}\text { Early } \\
\text { Announcement }\end{array}$ & $\mathrm{Y}$ \\
\hline Ukraine-Uzbekistan ${ }^{\mathrm{a}}$ & 1996 & & Y & $\mathrm{Y}$ \\
\hline
\end{tabular}

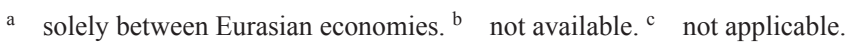

Source: WTO and the Global Preferential Trade Agreements Library accessed through WITS (2012). 
Table 19

STRI in Eurasia

\begin{tabular}{|c|c|c|c|c|c|}
\hline Country & Sector & Overall & Mode1 & Mode3 & Mode4 \\
\hline \multirow[t]{6}{*}{ Armenia } & Overall & 11.4 & 44.65 & 4.84 & 50 \\
\hline & Financial & 2.6 & 25.85 & 0 & \\
\hline & Telecommunications & 0 & & 0 & \\
\hline & Retail & 0 & & 0 & \\
\hline & Transportation & 25 & 50 & 25 & \\
\hline & Professional & 32 & 66.67 & 5 & 50 \\
\hline \multirow[t]{6}{*}{ Belarus } & Overall & 35.1 & 43.52 & 28.27 & 60 \\
\hline & Financial & 53.8 & 50.85 & 50 & \\
\hline & Telecommunications & 62.5 & & 62.5 & \\
\hline & Retail & 0 & & 0 & \\
\hline & Transportation & 36.8 & 50 & 27.27 & \\
\hline & Professional & 40 & 33.33 & 20 & 60 \\
\hline \multirow[t]{6}{*}{ Georgia } & Overall & 11.5 & 17.59 & 5.35 & 65 \\
\hline & Financial & 9 & 25.85 & 9.69 & \\
\hline & Telecommunications & 0 & & 0 & \\
\hline & Retail & 0 & & 0 & \\
\hline & Transportation & 8.8 & 37.5 & 0 & \\
\hline & Professional & 37 & 0 & 15 & 65 \\
\hline \multirow[t]{6}{*}{ Kazakhstan } & Overall & 17 & 18.96 & 11.38 & 60 \\
\hline & Financial & 22.1 & 25.85 & 25 & \\
\hline & Telecommunications & 25 & & 25 & \\
\hline & Retail & 0 & & 0 & \\
\hline & Transportation & 16.4 & 75 & 6.82 & \\
\hline & Professional & 28 & 0 & 5 & 60 \\
\hline \multirow[t]{6}{*}{ Kyrgyzstan } & Overall & 15.2 & 21.29 & 8.95 & 50 \\
\hline & Financial & 8.4 & 3.23 & 6.46 & \\
\hline & Telecommunications & 0 & & 0 & \\
\hline & Retail & 0 & & 0 & \\
\hline & Transportation & 45.7 & 75 & 40.91 & \\
\hline & Professional & 28 & 33.33 & 5 & 50 \\
\hline
\end{tabular}




\begin{tabular}{|c|c|c|c|c|c|}
\hline Country & Sector & Overall & Mode1 & Mode3 & Mode4 \\
\hline \multirow{6}{*}{$\begin{array}{l}\text { Russian } \\
\text { Federation }\end{array}$} & Overall & 25.7 & 22.44 & 18.78 & 70 \\
\hline & Financial & 46.7 & 32.31 & 50 & \\
\hline & Telecommunications & 50 & & 50 & \\
\hline & Retail & 0 & & 0 & \\
\hline & Transportation & 14.2 & 50 & 8.33 & \\
\hline & Professional & 32 & 0 & 0 & 70 \\
\hline \multirow[t]{6}{*}{ Ukraine } & Overall & 27.2 & 24.8 & 25.06 & 50 \\
\hline & Financial & 24.4 & 41.16 & 25 & \\
\hline & Telecommunications & 25 & & 25 & \\
\hline & Retail & 25 & & 25 & \\
\hline & Transportation & 26.7 & 37.5 & 20.83 & \\
\hline & Professional & 35 & 0 & 30 & 50 \\
\hline \multirow[t]{6}{*}{ Uzbekistan } & Overall & 23.4 & 27.07 & 22.48 & 35 \\
\hline & Financial & 24.6 & 29.08 & 25 & \\
\hline & Telecommunications & 50 & & 50 & \\
\hline & Retail & 0 & & 0 & \\
\hline & Transportation & 32 & 25 & 27.27 & \\
\hline & Professional & 31.5 & 25 & 30 & 35 \\
\hline
\end{tabular}

Source: World Bank’s Services Trade Restrictions Database (2012). 
Table 20

STRI in East Asia and the Pacific and the Europe Union

\begin{tabular}{|c|c|c|c|c|c|}
\hline Country & Sector & Overall & Mode1 & Mode3 & Mode4 \\
\hline \multirow[t]{6}{*}{ China } & Overall & 36.6 & 39.22 & 37.27 & 75 \\
\hline & Financial & 34.8 & 71.77 & 31.46 & \\
\hline & Telecommunications & 50 & & 50 & \\
\hline & Retail & 25 & & 25 & \\
\hline & Transportation & 19.3 & 37.5 & 22.22 & \\
\hline & Professional & 66 & 0 & 70 & 75 \\
\hline \multirow[t]{6}{*}{ European Union } & Overall & 26.1 & 34.17 & 26.18 & 60 \\
\hline & Financial & 4.2 & 34.69 & 0 & \\
\hline & Telecommunications & 0 & & 0 & \\
\hline & Retail & 25 & & 25 & \\
\hline & Transportation & 37.1 & 12.5 & 45.83 & \\
\hline & Professional & 54 & 41.67 & 50 & 60 \\
\hline \multirow[t]{6}{*}{ Indonesia } & Overall & 50 & 11.22 & 56.47 & 70 \\
\hline & Financial & 23.4 & 16.16 & 25 & \\
\hline & Telecommunications & 25 & & 25 & \\
\hline & Retail & 50 & & 50 & \\
\hline & Transportation & 66.4 & 25 & 72.22 & \\
\hline & Professional & 76 & 0 & 100 & 70 \\
\hline \multirow[t]{6}{*}{ Japan } & Overall & 23.4 & 36.58 & 23.41 & 60 \\
\hline & Financial & 1.9 & 19.39 & 0 & \\
\hline & Telecommunications & 25 & & 25 & \\
\hline & Retail & 25 & & 25 & \\
\hline & Transportation & 15.6 & 12.5 & 22.92 & \\
\hline & Professional & 56 & 66.67 & 50 & 60 \\
\hline \multirow[t]{6}{*}{ Korea Rep. } & Overall & 23.1 & 27.08 & 21.33 & 75 \\
\hline & Financial & 2.3 & 22.62 & 0 & \\
\hline & Telecommunications & 50 & & 50 & \\
\hline & Retail & 0 & & 0 & \\
\hline & Transportation & 20.8 & 25 & 20.83 & \\
\hline & Professional & 66 & 33.33 & 60 & 75 \\
\hline \multirow[t]{6}{*}{ Malaysia } & Overall & 46.1 & 32.49 & 46.52 & 90 \\
\hline & Financial & 44.6 & 30.27 & 50 & \\
\hline & Telecommunications & 25 & & 25 & \\
\hline & Retail & 25 & & 25 & \\
\hline & Transportation & 55.4 & 37.5 & 58.33 & \\
\hline & Professional & 73 & 33.33 & 65 & 90 \\
\hline
\end{tabular}

Source: World Bank's Services Trade Restrictions Database (2012). 